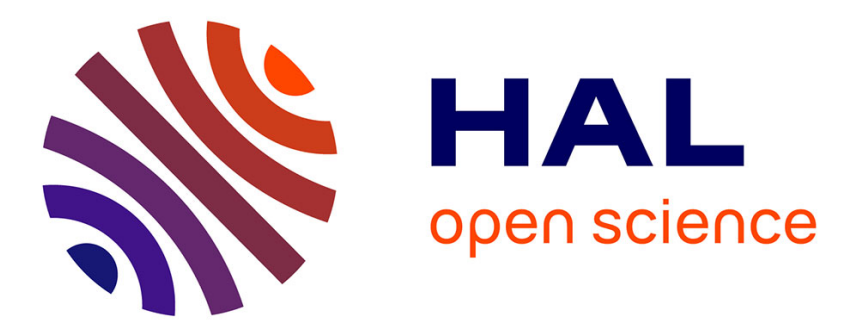

\title{
Penguins as bioindicators of mercury contamination in the southern Indian Ocean: geographical and temporal trends
}

\author{
Alice Carravieri, Yves Cherel, Audrey Jaeger, Carine Churlaud, Paco \\ Bustamante
}

\section{To cite this version:}

Alice Carravieri, Yves Cherel, Audrey Jaeger, Carine Churlaud, Paco Bustamante. Penguins as bioindicators of mercury contamination in the southern Indian Ocean: geographical and temporal trends. Environmental Pollution (1970), 2016, 213 (195-205), 10.1016/j.envpol.2016.02.010 . hal01330644

\section{HAL Id: hal-01330644 \\ https://hal.science/hal-01330644}

Submitted on 11 Jun 2016

HAL is a multi-disciplinary open access archive for the deposit and dissemination of scientific research documents, whether they are published or not. The documents may come from teaching and research institutions in France or abroad, or from public or private research centers.
L'archive ouverte pluridisciplinaire HAL, est destinée au dépôt et à la diffusion de documents scientifiques de niveau recherche, publiés ou non, émanant des établissements d'enseignement et de recherche français ou étrangers, des laboratoires publics ou privés. 
Penguins as bioindicators of mercury contamination in the Indian

Southern Ocean: geographical and temporal trends

Alice Carravieri ${ }^{\mathrm{a}, \mathrm{b}^{*}}$, Yves Cherel $^{\mathrm{a}}$, Audrey Jaeger ${ }^{\mathrm{a}, \mathrm{c}}$, Carine Churlaud ${ }^{\mathrm{b}}$, Paco

Bustamante $^{\mathrm{b}}$

${ }^{a}$ Centre d'Etudes Biologiques de Chizé, UMR 7372 CNRS-Université de La Rochelle, 79360 Villiers-en-Bois, France

${ }^{\mathrm{b}}$ Littoral Environnement et Sociétés (LIENSs), UMR 7266 CNRS-Université de La Rochelle, 2 rue Olympe de Gouges, 17000 La Rochelle, France

${ }^{c}$ Centre de Recherche et de Veille sur les Maladies Emergentes dans l'Océan Indien, Saint-Denis, La Réunion, France

*corresponding author: Alice Carravieri

Station d'Ecologie de Chizé

UMR 7372

CNRS-Université de La Rochelle

79360 Villiers-en-Bois (France)

Tel : $+\underline{33(0) 549099618}$

E-mail : alice.carravieri@gmail.com 
Abstract: Penguins have been recently identified as useful bioindicators of mercury $(\mathrm{Hg})$ transfer to food webs in the Southern Ocean over different spatial and temporal scales. Here, feather $\mathrm{Hg}$ concentrations were measured in adults and chicks of all the seven penguin species breeding in the southern Indian Ocean, over a large latitudinal gradient spanning Antarctic, subantarctic and subtropical sites. $\mathrm{Hg}$ was also measured in feathers of museum specimens of penguins collected at the same sites in the 1950s and 1970s. Our aim was to evaluate geographical and historical variation in $\mathrm{Hg}$ transfer to penguins, while accounting for feeding habits by using the stable isotope technique $\left(\delta^{13} \mathrm{C}\right.$, habitat; $\delta^{15} \mathrm{~N}$, diet/trophic level). Adult feather Hg concentrations in contemporary individuals ranged from $0.7 \pm 0.2$ to $5.9 \pm 1.9 \mu \mathrm{g} \mathrm{g}^{-1} \mathrm{dw}$ in Adélie and gentoo penguins, respectively. Interspecific differences in $\mathrm{Hg}$ accumulation were strong among both adults and chicks, and mainly linked to feeding habits. Overall, penguin species that feed in Antarctic waters had lower feather $\mathrm{Hg}$ concentrations than those that feed in subantarctic and subtropical waters, irrespective of age class and dietary group, suggesting different $\mathrm{Hg}$ incorporation into food webs depending on the water mass. While accounting for feeding habits, we detected different temporal variations in feather $\mathrm{Hg}$ concentrations depending on species. Notably, the subantarctic gentoo and macaroni penguins had higher $\mathrm{Hg}$ burdens in the contemporary rather than in the historical sample, despite similar or lower trophic levels, respectively. Whereas increases in $\mathrm{Hg}$ deposition have been recently documented in the Southern Hemisphere, future monitoring is highly needed to confirm or not this temporal trend in penguins, especially in the context of actual changing $\mathrm{Hg}$ emission patterns and global warming.

Keywords: Antarctica; Indian Ocean; Metal; Museum specimen; Seabird; Stable isotopes 


\section{Highlights}

- Feather Hg levels were measured in 7 penguin species from the southern Indian Ocean

- Species and feeding habits were key determinants of both adult and chick Hg levels

- Antarctic species had lower Hg burdens than subantarctic and subtropical ones

- Some subantarctic species had higher Hg burdens today than in the 1970s

- Future Hg evaluation is needed in lower trophic level biota from the Southern Ocean

\section{Introduction}

Mercury $(\mathrm{Hg})$ is a highly-toxic nonessential metal of global concern. Under its inorganic form, $\mathrm{Hg}$ is highly volatile, and can be transported over inter-continental distances (UNEP 2013). Atmospheric deposition is the main input of $\mathrm{Hg}$ to the open ocean (e.g., Mason et al. 2012, Driscoll et al. 2013). Hence, Hg is widely distributed in oceanic waters, with the concentrations of the different chemical species varying horizontally and vertically depending on a multitude of biotic and abiotic factors (Fitzgerald et al. 2007). Under the organic form (methyl-Hg, $\mathrm{Me}-\mathrm{Hg}$ ), $\mathrm{Hg}$ bioaccumulates in the tissues of marine organisms and biomagnifies up food webs (Cossa 2013), exerting deleterious effects such as endocrine disruption and neurodevelopmental impairment in apex predators (Wolfe et al. 1998, Dietz et al. 2013, Tartu et al. 2013). Anthropogenic perturbations to the global $\mathrm{Hg}$ cycle have tripled the total $\mathrm{Hg}$ content of surface oceanic waters compared to preanthropogenic conditions, and also significantly increased total $\mathrm{Hg}$ concentration in intermediate and deep waters (Driscoll et al. 2013, Lamborg et al. 2014). In the Northern Hemisphere, growing oceanic $\mathrm{Hg}$ concentrations have been associated to increasing $\mathrm{Hg}$ bioaccumulation in marine biota, such as marine mammals and seabirds (Monteiro and Furness 1997, Braune et al. 2005, Bond et al. 2015). Nevertheless, data on $\mathrm{Hg}$ 
concentrations and transfer to food webs, and their spatial and temporal trends, are still very scarce in oceanic waters of the Southern Hemisphere. This is particularly true for the southern Indian Ocean, with no data on temporal variations in seawater $\mathrm{Hg}$ patterns, only limited information on $\mathrm{Hg}$ distribution and speciation (Cossa et al. 2011, Lamborg et al. 2014), and some information on bioaccumulation in biota (e.g., Bocher et al. 2003, Carravieri et al. 2014a, Fontaine et al. 2015).

Seabirds have been used extensively as bioindicators of $\mathrm{Hg}$ contamination of their food webs (Furness and Camphuysen 1997). Like other apex predators, seabirds are mainly exposed to $\mathrm{Hg}$ through food ingestion, and feeding ecology has been shown to be the main driver of between- and within-species variations of $\mathrm{Hg}$ concentration in their tissues (Becker et al. 2002, Bearhop et al. 2000, Carravieri et al. 2014a,b). After absorption by the gut, $\mathrm{Hg}$ contained in prey is highly assimilated in internal tissues, mainly the liver, kidney and muscle (Walker et al. 2012), and it is efficiently excreted through the moult over a regular basis (Furness et al. 1986, Monteiro and Furness 2001). Feather $\mathrm{Hg}$ concentrations constitute thus a pertinent proxy of the $\mathrm{Hg}$ body burden (Thompson et al. 1998), and are commonly used for seabird Hg biomonitoring over the short- and long-term (Burger and Gochfeld 2004). Recent studies of our group using seabirds suggest that $\mathrm{Hg}$ food web transfer to predators has a latitudinal trend in the southern Indian Ocean, increasing from Antarctic, through subantarctic, to subtropical waters (Blévin et al. 2013, Carravieri et al. 2014b, Goutte et al. 2013). This trend should however be confirmed by multi-sites and multi-species studies, and discussed in the light of the pioneer data on Me-Hg distribution in Southern Ocean waters (Cossa et al. 2011, Lamborg et al. 2014). Moreover, only one previous study has evaluated historical variations in $\mathrm{Hg}$ concentrations in a single seabird species in the southern Indian Ocean 
(Scheifler et al. 2005), and there is urgent need to investigate long-term temporal trends in this remote oceanic region.

Penguins represent the greatest seabird biomass in the Southern Ocean (Williams 1995) and are particularly pertinent as bioindicator species of $\mathrm{Hg}$ food web contamination. Indeed, penguin species have almost constant trophic niches over the short- (breeding period) to long-term (wintering), and remain confined to the Southern Ocean year-round (e.g., Thiebot et al. 2011a,b, 2012). Furthermore, penguins moult annually their entire plumage over a short-period, while fasting ashore (Williams 1995, Cherel et al. 1994), reducing within-individual variations of $\mathrm{Hg}$ concentrations in their feathers (Carravieri et al. 2014c, Brasso et al. 2013). By using penguins as bioindicators, and as a companion investigation to Carravieri et al. (2013), the main aim of this study was to describe spatio-temporal variations in $\mathrm{Hg}$ transfer to these avian predators at different latitudes of the southern Indian Ocean. To this end, feather $\mathrm{Hg}$ has been measured in all penguin species breeding in the French Austral Territories (TAAF) over a large geographical range, from high-Antarctica to the subtropics, during the same breeding season in 2006-2007. Moreover, feathers were obtained from museum specimens of penguins collected at the same sites during the 1950s to the 1970s. Potential spatio-temporal variations in feeding ecology have been taken into account using stable isotopes of carbon $\left(\delta^{13} \mathrm{C}\right)$ and nitrogen $\left(\delta^{15} \mathrm{~N}\right)$, which are known proxies of feeding habitat and trophic position, respectively (Vanderklift and Ponsard 2003, Newsome et al. 2007). $\mathrm{Hg}$ and stable isotopes have been measured in feathers from both adults and chicks at each site. Chicks were expected to show lower feather $\mathrm{Hg}$ concentrations than adults, because of their shorter period of exposure. Given the previous results on the latitudinal differences in Hg transfer to predators in the southern Indian Ocean (Blévin et al. 2013, Carravieri et al. 2014b, Goutte et al. 2013), we expected increasing Hg concentrations in 
the feathers of penguin populations breeding from high to low latitudes. Finally, given the increasing trends of $\mathrm{Hg}$ deposition in the Southern Hemisphere (e.g., Hermanns and Biester 2013) and of $\mathrm{Hg}$ bioaccumulation in marine animals (e.g., Vo et al. 2011, Bond et al. 2015), we expected feather $\mathrm{Hg}$ concentrations of contemporary penguins to be higher than those of museum specimens from the 50 s and 70 s.

\section{Material and methods}

Study site, species and field collections

Fieldwork was conducted at three sites of the French Southern and Antarctic Territories, that are representative of different water masses, namely Adélie land $\left(66^{\circ} 40^{\prime} \mathrm{S}, 140^{\circ} 01^{\prime} \mathrm{E}\right)$ in high-Antarctica, the Crozet Islands $\left(46^{\circ} 26^{\prime} \mathrm{S}, 51^{\circ} 45^{\prime} \mathrm{E}\right)$ in the subantarctic zone sensus lato (between the Polar and the Subtropical Fronts), and Amsterdam Island (37 $50^{\circ} \mathrm{S}$, $77^{\circ} 31^{\prime} \mathrm{E}$ ) in the subtropics (north the Subtropical Front). All the seven penguin species breeding at these sites were sampled: emperor Aptenodytes forsteri and Adélie Pygoscelis Adeliae penguins at Adélie land; king Aptenodytes patagonicus, macaroni Eudyptes chrysolophus, southern rockhopper Eudyptes chrysocome filholi and gentoo penguins Pygoscelis papua at Crozet Islands; and northern rockhopper penguins Eudyptes moseleyi at Amsterdam Island.

Penguin moult involves two distinct processes, with new feather synthesis and old feather loss overlapping in mid-moult (Cherel et al. 1994). Thus, for the contemporary sample, both new and old feathers from the same individual adult penguins were collected in mid-moult, in order to evaluate potential inter-annual variation of adult penguins $\mathrm{Hg}$ exposure at the individual scale. Old and new feathers refer to moults that occurred during the 2005-2006 and 2006-2007 austral summers (hereafter called 2006 and 2007), 
respectively. Emperor penguin feathers were collected on breeding, not moulting birds, because, unlike other penguins, adult emperor penguins do not moult at the breeding sites. Inter-annual variations in feather $\mathrm{Hg}$ content were thus evaluated in six species only. Feathers (2007 moult) were also sampled from chicks at fledging (i.e. at the end of the breeding season). Historical feather samples (from 1950 to 1977) were obtained from specimens held in the ornithological collection of the Muséum National d'Histoire Naturelle of Paris (France). Feathers were taken only when complete capture information was present with a particular study specimen. Between 6 and 10 body feathers per individual (or museum specimen) were collected and stored dry in sealed plastic bags until analysis at the University of La Rochelle, France.

\section{Sample analyses}

Prior to chemical analysis, feathers were cleaned to remove surface lipids and contaminants as previously described (Carravieri et al. 2013). Since almost all $\mathrm{Hg}$ is under the organic form in feathers, total $\mathrm{Hg}$ approximates the amount of feather $\mathrm{Me}-\mathrm{Hg}$ (Bond and Diamond 2009, Thompson and Furness 1989). Total Hg was also quantified in feathers of museum specimens, because Hg-containing preservatives were not used at the Muséum National d'Histoire Naturelle of Paris at the time the museum specimens were collected, avoiding a potential contamination (Vo et al. 2011). Following recommendations in Carravieri et al. (2014c), only one individual feather per penguin was analysed for total $\mathrm{Hg}$ in an Advanced Mercury Analyzer spectrophotometer (Altec AMA 254). All analyses were repeated 2-3 times until having a relative standard deviation $<10 \%$. Accuracy was checked using a certified reference material (Tort-2 Lobster Hepatopancreas, NRC, Canada; certified $\mathrm{Hg}$ concentration: $0.27 \pm 0.06 \mu \mathrm{g} \mathrm{g}^{-1}$ dry mass). Our measured values were $0.226 \pm 0.003 \mu \mathrm{g} \mathrm{g}^{-1}$ dry mass, $n=7$. Blanks were 
analysed at the beginning of each set of samples and the detection limit of the method was $0.005 \mu \mathrm{g} \mathrm{g}^{-1}$ dry mass. Data of $\mathrm{Hg}$ concentrations are presented relative to the dry weight $(\mathrm{dw})$.

After the cleaning procedure, an individual feather per penguin was homogenized by cutting it with scissors into small fragments, weighed $(\sim 0.3 \mathrm{mg})$ with a microbalance and packed into tin containers. The relative abundance of carbon and nitrogen isotopes were determined with a continuous flow mass spectrometer (Thermo Scientific Delta V Advantage) coupled to an elemental analyser (Thermo Scientific Flash EA 1112). Isotopic values are presented in the usual $\delta$ notation relative to Vienna PeeDee Belemnite and atmospheric $\mathrm{N}_{2}$ for $\delta^{13} \mathrm{C}$ and $\delta^{15} \mathrm{~N}$, respectively. Replicate measurements of internal laboratory standards (acetanilide) indicated measurement errors $<0.15 \%$ for both $\delta^{13} \mathrm{C}$ and $\delta^{15} \mathrm{~N}$ values. Results of $\delta^{13} \mathrm{C}$ and $\delta^{15} \mathrm{~N}$ values of adult penguins, but not chicks, were previously used to investigate historical changes in the isotopic niches of penguins (Jaeger and Cherel 2011). In the present study, the isotopic data have been exploited again in order to evaluate geographical and temporal trends in $\mathrm{Hg}$ bioaccumulation in penguins while accounting for potential changes in their feeding ecology. In long-term analyses using contemporary and historical samples, the raw $\delta^{13} \mathrm{C}$ values of adult penguin feathers were adjusted following Hilton et al. (2006) and Jaeger and Cherel (2011) by taking into account the two effects resulting from human fossil fuel burning: first, the Suess effect (fossil carbon introduced into the atmosphere has a lower $\delta^{13} \mathrm{C}$ than background carbon, Keeling 1979) and second, the effect of the increase in atmospheric $\mathrm{CO}_{2}$ and thus aqueous $\mathrm{CO}_{2}$, which increases phytoplankton fractionation, reducing its $\delta^{13} \mathrm{C}$ values (Rau et al. 1992). 


\section{Statistical analyses}

All statistical analyses were performed using R 2.15.1 (R Core Team 2012). Data were first checked for normality and homogeneity of variances by means of Shapiro-Wilk and Bartlett tests, respectively. Depending on the results, parametric or non-parametric tests were used. In order to test differences between contemporary and historical feather $\mathrm{Hg}$, $\delta^{13} \mathrm{C}$ and $\delta^{15} \mathrm{~N}$ values a categorical variable (epoch) was used rather than a continuous time-series, because of the small sample size and of the variability of the date of collection of museum specimens depending on species. Multifactorial analyses were realised in order to identify the most influential parameters in describing geographical and temporal variation in feather $\mathrm{Hg}$ concentrations. The models were restricted to primary effects (explanatory variables: species, $\delta^{13} \mathrm{C}, \delta^{15} \mathrm{~N}$ and/or epoch) and two-way interactions. Feather $\delta^{13} \mathrm{C}$ and $\delta^{15} \mathrm{~N}$ values were fitted in the same models since no collinearity was detected (all variance inflation factors $<2$, Zuur et al. 2010). Forward selection using the Akaike's Information Criterion corrected for small sample sizes (AICc) (Burnham and Anderson 2002) was applied. Since our aim was to make inference on the variables affecting contaminant burdens, the effect of variables was inferred through Akaike's weights (Burnham and Anderson 2002). Model fit was checked by residual analysis (Zuur et al. 2009). A significance level of $\alpha<0.05$ was used for all tests, both in unifactorial and multifactorial analysis. Values are means $\pm \mathrm{SD}$. 


\section{Results}

Latitudinal variation in adult and chick feather $\mathrm{Hg}$ concentrations and influence of species and feeding habits

Feather $\mathrm{Hg}$ and $\delta^{13} \mathrm{C}$ and $\delta^{15} \mathrm{~N}$ values were measured in 170 individual penguins, including adults and chicks, during the 2006-2007 austral summer season. Among adult penguins, there was a 9-fold difference in $\mathrm{Hg}$ concentrations between the least and the most contaminated species, namely the Adélie and gentoo penguins, respectively (Table 2). Based on 2007 feathers, interspecific differences were strong and significant (KruskalWallis, $\mathrm{H}=67, p<0.0001$, Table 2), with Antarctic species having lower feather $\mathrm{Hg}$ concentrations than subantarctic and subtropical species, irrespective of the dietary group (mainly fish- or mainly crustacean-feeders, Fig. 1). Feather $\delta^{13} \mathrm{C}$ and $\delta^{15} \mathrm{~N}$ values differed widely among adult penguins (ANOVA, $\mathrm{F}_{6,79}=399$ and 68, respectively, both $p<$ 0.0001), with each species having a unique isotopic niche (Table 2). Multifactorial analyses showed that the species and the $\delta^{15} \mathrm{~N}$ signature had the greatest explanatory power of adult feather $\mathrm{Hg}$ concentrations at the different sites, while $\delta^{13} \mathrm{C}$ signature had a secondary role (Table 3).

Chicks had systematically lower feather $\mathrm{Hg}$ concentrations than adults, irrespective of species, dietary group or site (Wilcoxon comparisons, $100<\mathrm{W}<170$, all $p<0.0001)$. Inter-specific differences in feather $\mathrm{Hg}$ concentrations in chicks were significant (Kruskal-Wallis, $\mathrm{H}=72, p<0.0001$ ). Among chicks, the seven species ranked in a relatively different order than adults (Table 2), but still Antarctic species had lower feather $\mathrm{Hg}$ concentrations than subantarctic and subtropical species. Isotopic niches were different depending on species (ANOVA, $\mathrm{F}_{6,76}=691$ and 103 for $\delta^{13} \mathrm{C}$ and $\delta^{15} \mathrm{~N}$ values, respectively, both $p<0.0001$ ), with the exception of macaroni and gentoo penguin chicks 
at Crozet Islands, which had similar feather $\delta^{13} \mathrm{C}$ and $\delta^{15} \mathrm{~N}$ values (Table 2). Multifactorial analyses revealed that, in contrast to adults, the $\delta^{13} \mathrm{C}$ signature was as important as the species in explaining variation of chick feather $\mathrm{Hg}$ concentrations (Table 3).

Temporal variation in adult feather $\mathrm{Hg}$ concentrations and influence of species and feeding habits

\section{Inter-annual variation}

Adult feather $\mathrm{Hg}$ concentrations were similar in 2006 and 2007 in king and gentoo penguins (pairwise Wilcoxon comparisons, $\mathrm{V}=50$ and $16, p=0.424$ and 0.148 , respectively). On the other hand, feather $\mathrm{Hg}$ concentrations were higher in 2007 than in 2006 in Adélie, macaroni and southern rockhopper penguins ( $\mathrm{V}=2,3$ and 10, $p=0.006$, 0.002 and 0.045 , respectively), while they were lower in 2007 than 2006 in northern rockhopper penguins $(\mathrm{V}=67, p=0.027)$. Feather $\mathrm{Hg}$ concentrations were highly and positively correlated between the two years at the individual level (pooled data from six species; Pearson correlation, $\mathrm{r}=0.93, p<0.0001, \mathrm{n}=69$, Fig. 2).

\section{Historical variation}

$\mathrm{Hg}$ and stable isotope values were measured in a total of 62 museum specimens of five penguin species dating back to the 50s-70s, and compared to contemporary 2007 values (see Table S1 in the Supplementary Information, SI). Feather Hg concentrations did not show a consistent temporal trend among species. In Antarctica, Adélie penguins had lower feather $\mathrm{Hg}$ concentrations in 2007 than in the 50s (Wilcoxon comparisons, $\mathrm{W}=50$, $p=0.001$, Fig. 3), while emperor penguins had similar concentrations $(\mathrm{W}=97, p=0.888$, Fig. 3). Conversely, at Crozet Islands, macaroni and gentoo penguins had higher feather $\mathrm{Hg}$ concentrations in 2007 than in the 70 s $(\mathrm{W}=36$ and $10, p=0.002$ and $p<0.001$, respectively, Fig. 4), whereas king penguins had unchanged burdens ( $\mathrm{W}=65, p=0.157$, 
Fig. 4). Feather $\delta^{13} \mathrm{C}$ and $\delta^{15} \mathrm{~N}$ values did not show a consistent temporal trend either (see Table S1 in the SI). Notably, $\delta^{15} \mathrm{~N}$ values were significantly lower in 2007 than in the historical samples in emperor and macaroni penguins (Welsh two sample $t$ test, $t=2.3$ and 2.4, p = 0.034 and 0.033, respectively, Fig. 3 and 4). Multifactorial analyses indicated that the species, epoch and the $\delta^{13} \mathrm{C}$ and $\delta^{15} \mathrm{~N}$ signatures all were significant in explaining variation in feather $\mathrm{Hg}$ concentrations, with the maximal model having the best fit to the data (Table 3).

\section{Discussion}

The present study documents new information on $\mathrm{Hg}$ bioaccumulation in penguins from different latitudes of the Southern Ocean, including the first data on feather $\mathrm{Hg}$ concentrations of northern rockhopper penguins. Importantly, and with the only exception of king penguins (Scheifler et al. 2005), this is the first report of historical feather $\mathrm{Hg}$ concentrations in seabirds from the southern Indian Ocean, revealing contrasting temporal trends depending on species.

\section{Comparison to other penguin populations throughout the Southern Hemisphere}

As useful bioindicators of $\mathrm{Hg}$ contamination in their food webs, penguins are the target of a growing number of studies investigating their pattern of contamination all around the Southern Hemisphere (e.g., Carravieri et al. 2013, Brasso et al. 2015, Pedro et al. 2015). Feather $\mathrm{Hg}$ concentrations were previously investigated in king penguins at the Crozet Islands (Scheifler et al. 2005), revealing comparable results to the present study. $\mathrm{Hg}$ concentrations and inter-specific differences of the Crozet penguin community were remarkably similar to those of Kerguelen Islands (southern Indian Ocean), where the 
same four species breed (Carravieri et al. 2013, Blévin et al. 2013). Overall, feather Hg concentrations of TAAF penguins were comparable to previous studies from the Atlantic and Pacific sectors of the Southern Ocean (e.g., Brasso et al. 2015), with Eudyptes and Pygoscelis penguins having usually lower feather $\mathrm{Hg}$ burdens than Aptenodytes penguins, likely because they feed at lower trophic levels (Becker et al. 2002, Carravieri et al. 2013, see below). King and macaroni penguins had similar or slightly lower feather $\mathrm{Hg}$ concentrations to those of South Georgia (southern Atlantic Ocean) populations (Table 4), and both emperor and Adélie penguins at Terre Adélie had similar or slightly higher feather Hg concentrations than those reported at other Antarctic sites (Bargagli et al. 1998, Table 4). The single and remarkable exception to this general pattern is that of gentoo penguins (genus Pygoscelis), which, at Crozet Islands, had the highest mean feather $\mathrm{Hg}$ concentrations ever reported in penguins. This high $\mathrm{Hg}$ burden is similar to that of the Cape Estacade subpopulation at the Kerguelen Islands (Carravieri et al. 2013, Table 4), therefore indicating the high quantity of $\mathrm{Hg}$ contained in the prey of gentoo penguins at both subantarctic sites, i.e. a mixture of benthic and demersal fish and pelagic crustaceans from coastal environments (Ridoux 1994, Lescroël et al. 2004, Cherel and Hobson 2007, Table 1). By contrast, gentoo penguin feather $\mathrm{Hg}$ concentrations were lower at other subantarctic and Antarctic sites (Table 4), where the species relies more largely on lowtrophic level prey (e.g., Antarctic krill Euphausia superba, Brasso et al. 2014, Pedro et al. 2015) with lower Hg concentrations compared to fish (e.g., Goutte et al. 2015). The high variability in feather $\mathrm{Hg}$ concentrations of gentoo penguins is thus likely linked to the variability of feeding habits both at the individual and population levels (Lescroël et al. 2004, Miller et al. 2009, Carravieri et al. 2013). 
Influence of age class, species and feeding habits on feather $\mathrm{Hg}$ burdens

Feather $\mathrm{Hg}$ burdens were lower in chicks than in adults in all the seven species studied, as previously shown in other penguins (Bargagli et al. 1998, Carravieri et al. 2013) and seabirds (e.g., Carravieri et al. 2014a, Catry et al. 2008, Bond and Diamond 2009). Lower feather $\mathrm{Hg}$ concentrations in chicks have been attributed to their short period of exposure (the chick-rearing period) when compared to adults (inter-moult period, one year) (Burger and Gochfeld 2004). Hence, the duration of the chick-rearing period influences the adult to chick ratio in $\mathrm{Hg}$ burdens (Furness et al. 1990), i.e., species having long chickrearing periods have low ratios, as shown in king penguins (Carravieri et al. 2013, this study, Table 2). Nevertheless, variations of feather $\mathrm{Hg}$ levels in adults and chicks are also driven by age class differences in diet (Carravieri et al. 2014a), since in some species adults feed their chicks with different prey than those they consume themselves, both during the breeding and non-breeding periods (e.g., Wilson et al. 2004, Cherel 2008).

For both adults and chicks, the species was the main factor explaining variation in feather Hg levels (Table 3). The species indeed integrates physiological and ecological traits that may drive variation in $\mathrm{Hg}$ exposure and bioaccumulation (e.g., Anderson et al. 2009). However, the main factors explaining inter-species differences in $\mathrm{Hg}$ burdens are feeding habits, rather than physiological or taxonomic differences (Stewart et al. 1999, Anderson et al. 2009, Carravieri et al. 2014a). Given Hg biomagnification in the marine environment (Chen et al. 2008, Mason et al. 2012), high trophic level prey, such as fish and cephalopods, show higher $\mathrm{Hg}$ concentrations than planktonic organisms (Bustamante et al. 2006, Kojadinovic et al. 2006, Stewart et al. 1997), resulting in higher Hg transfer to their consumers. As expected, species feeding mainly on fish had higher feather $\mathrm{Hg}$ concentrations than those relying mainly on crustaceans, both at the Antarctic and subantarctic sites, and among both adults and chicks (Fig 1 and Tables 1 and 2). Namely, 
the Antarctic emperor penguins that feed extensively on pelagic fish had higher feather $\mathrm{Hg}$ concentrations than the sympatric Adélie penguins that rely mainly on crustaceans. Similarly, subantarctic king penguins that prey almost exclusively on myctophid fish had higher $\mathrm{Hg}$ burdens than the sympatric southern rockhopper penguins that rely on pelagic crustaceans. Hence, the trophic position (inferred from $\delta^{15} \mathrm{~N}$ values) had a significant effect in explaining both geographical and temporal variation in feather $\mathrm{Hg}$ concentrations of adults (Table 2). The $\delta^{13} \mathrm{C}$ value, on the other hand, had strong statistical power in explaining variation in $\mathrm{Hg}$ burdens in chicks. This indicates that penguin chicks were exposed to different $\mathrm{Hg}$ quantities depending on the habitats used by their parents to capture prey. The weak effect of feeding habitat on adult feather $\mathrm{Hg}$ concentrations is likely linked to the slight temporal uncoupling of stable isotopes and $\mathrm{Hg}$ integration in adult feathers (e.g., Thompson et al. 1998), with $\mathrm{Hg}$ concentrations reflecting accumulated burdens over the breeding, pre-moulting and wintering periods, while the habitat inferred from $\delta^{13} \mathrm{C}$ signatures indicate the pre-moulting feeding habitat only (e.g., Cherel et al. 2005). This result also highlights that chicks may be more suitable as local biomonitors of $\mathrm{Hg}$ accumulation than adults, because their exposure can be better ascertained both spatially and temporally (Becker et al. 1993, Burger and Gochfeld 2004).

\section{Latitudinal variation within the southern Indian Ocean}

The present study shows that high-Antarctic species had lower feather Hg concentrations than subantarctic and subtropical species (Fig. 1), irrespective of age class and dietary group. Namely, among crustacean-eating species, Adélie penguins that feed in oceanic Antarctic waters year-round (Table 1), had less than half the feather $\mathrm{Hg}$ concentrations of the subantarctic southern rockhopper penguins. Similarly, among fish-eaters, emperor penguins, which rely on Antarctic waters, had lower $\mathrm{Hg}$ concentrations than king 
penguins that forage almost exclusively in oceanic subantarctic waters. Geographical variations in penguin $\mathrm{Hg}$ burdens seem thus to derive from differential $\mathrm{Hg}$ transfer to food webs depending on the water mass, rather than from dietary differences. Such a geographical variation has not been shown in other penguin populations from around the Southern Hemisphere (Table 4). Nevertheless, a similar trend was previously reported at the Kerguelen Islands, where oceanic seabird species feeding in cold Antarctic waters had lower feather $\mathrm{Hg}$ concentrations than those relying on warmer northern waters (Blévin et al. 2013, Carravieri et al. 2014a). Surprisingly, the only biogeochemical survey on $\mathrm{Hg}$ speciation and distribution in the Southern Ocean has shown that Antarctic waters are enriched with $\mathrm{Me}-\mathrm{Hg}$, the bioavailable form that is readily transferred to food webs, when compared to subantarctic waters (Cossa et al. 2011). Lower Hg burdens in Antarctic than subantarctic predators are therefore contradictory. Yet, several biotic and abiotic factors influence $\mathrm{Hg}$ bioavailability and food web transfer, including atmospheric $\mathrm{Hg}$ deposition rate, oxygen and organic matter concentrations, microbial activity, temperature (e.g., Fitzgerald et al. 2007) and, importantly, food web structure (Cabana and Rasmussen 1994, Point et al. 2011, Braune et al. 2014). An increasing number of trophic levels between predators and their prey thus results in higher $\mathrm{Hg}$ concentrations in the predators' tissues (Cabana et al. 1994). Antarctic food webs are rather simple, with upper predators relying directly or indirectly on a few key species, such as the Antarctic krill E. superba and Antarctic silverfish (e.g., Corsolini 2009). Conversely, predators in subantarctic food webs feed on a large variety of prey species (e.g., Cherel et al. 2007). A weaker biomagnification of $\mathrm{Hg}$ due to low food web complexity, despite relatively high $\mathrm{Me}-\mathrm{Hg}$ concentrations in the water (Cossa et al. 2011), could explain the low $\mathrm{Hg}$ burden in highAntarctic seabirds. 
Temporal variation within the southern Indian Ocean

\section{Inter-annual variation}

In the marine environment, the quantity of $\mathrm{Hg}$ available to predators may change annually as a consequence of differences in $\mathrm{Hg}$ deposition and in situ methylation rates, in phytoplankton intake and biomass, among other factors (Fitzgerald et al. 2007, Driscoll et al. 2013). Changes in feeding strategies or in the way $\mathrm{Hg}$ is transferred within food webs can also lead to annual differences in $\mathrm{Hg}$ concentrations in predators' tissues (Braune et al. 2014, Bond et al. 2015). Nevertheless, in remote marine regions that are subject to global rather than point sources of $\mathrm{Hg}$, inter-annual differences in feather $\mathrm{Hg}$ contamination of seabirds have been found to be negligible (Scheifler et al. 2005, Carravieri et al. 2013, Brasso et al. 2014). In the present study only two (king and gentoo) out of six penguin species showed no inter-annual variation in feather $\mathrm{Hg}$ concentrations, while the other species showed a temporal increase (Adélie, macaroni and southern rockhopper) or decrease (northern rockhopper penguins) between 2006 and 2007. Since no inter-annual variation in feather stable isotopes values was reported in these individuals (Jaeger and Cherel 2011), the temporal change in $\mathrm{Hg}$ exposure is likely due to environmental factors rather than to a dietary change. This is supported by the fact that at the individual level, $\mathrm{Hg}$ exposure was similar in both years, i.e., individuals with a high feather $\mathrm{Hg}$ concentrations in one year, had also high concentrations in the following one (Fig. 2), especially in species with high intra-specific variation in $\mathrm{Hg}$ concentrations (gentoo penguins). This corroborates the results from previous studies (Scheifler et al. 2005, Carravieri et al. 2013) suggesting that individuals may vary in their ability to excrete $\mathrm{Hg}$ in their feathers and/or that individuals have consistent feeding strategies (and thus $\mathrm{Hg}$ exposure) over the long-term, as previously shown in seabirds (e.g., Ceia et al. 2012). 


\section{Historical variation}

Since $\mathrm{Hg}$ is strongly bound to feather keratin, resisting vigorous chemical treatments (Appelquist et al. 1984), archives of feather samples from museum skins have served widely to investigate long-term temporal trends in seabird $\mathrm{Hg}$ exposure. Significant increases in feather $\mathrm{Hg}$ concentrations have been detected in seabirds from the Arctic (e.g., Muir et al. 1999, Dietz et al. 2009, Bond et al. 2015), North Atlantic (Thompson et al. 1992, Monteiro and Furness 1997) and Pacific (Vo et al. 2011) Oceans during the last century. Here, contrary to our prediction, long-term temporal variation in feather $\mathrm{Hg}$ concentrations in Southern Ocean penguins did not indicate a consistent increase, but instead varied in different ways depending on species. Notably, in Antarctica, no change in penguin $\mathrm{Hg}$ bioaccumulation can be clearly ruled out, since 1) feather $\mathrm{Hg}$ concentrations in emperor penguins were similar in the 50s and contemporary groups; and 2) while Adélie penguins showed a significant decrease between the two time periods $(-77 \%)$, the small sample size and the high between-individual variation of the historical samples call for caution in the interpretation (Fig. 3). Conversely, results in subantarctic species offer a different picture. Namely, macaroni and gentoo penguins had significantly higher feather $\mathrm{Hg}$ concentrations in present-day than in the 70 s $(+32 \%$ and $+53 \%$, respectively, Fig. 4). The same trend was true in king penguins, although not significantly so $(+14 \%$, Fig. 4 , but see Scheifler et al. 2005). While gentoo and king penguins had similar $\delta^{15} \mathrm{~N}$ values at both time periods, macaroni penguins occupied a lower position in 2007. Taking into account $\mathrm{Hg}$ biomagnification, the detected increase in feather $\mathrm{Hg}$ concentrations of macaroni penguins is contradictory, and thus strongly suggests that it was linked to increasing $\mathrm{Hg}$ concentrations in the food web rather than to a dietary shift (Bond et al. 2015). Other subantarctic seabirds have been reported to have increasing feather $\mathrm{Hg}$ concentrations (i.e., black-browed Thalassarche melanophrys and grey- 
headed T. chrysostoma albatrosses, South Georgia, Becker et al. 2002), although potential temporal changes in feeding habits were not simultaneously assessed. In contrast to results from Northern Hemisphere biota, there is therefore a lack of a significant, consistent increase in $\mathrm{Hg}$ burdens in seabird species from the Southern Ocean in the past century (Thompson et al. 1993, Becker et al. 2002, Scheifler et al. 2005, present work). This may indicate that $\mathrm{Hg}$ transfer to Southern Ocean predators has remained relatively constant in this time period, in accordance with the lower anthropogenic emissions and deposition rates that have characterised the Southern Hemisphere when compared to the Northern one (e.g., UNEP 2013). Nevertheless, the increase detected here in subantarctic species may be indicative of recent changes of $\mathrm{Hg}$ emission and/or deposition patterns, linked to the development of Asian and Southern Hemisphere countries, as shown by increased $\mathrm{Hg}$ deposition in peat cores and lake sediments in the Southern Hemisphere (e.g., Hermanns and Biester 2013). Since there is an important temporal lag before that changes in $\mathrm{Hg}$ atmospheric patterns are mirrored in $\mathrm{Hg}$ deposition, circulation and food web transfer in the ocean (Driscoll et al. 2013, UNEP 2013), future increasing trends in marine biota from the Southern Ocean could be expected. Therefore, continuous monitoring is highly needed to confirm or not these trends in penguins, by using larger sample sizes and a larger time-window, and by taking into account potential dietary preference change over time (Braune et al. 2014, Bond et al. 2015).

\section{Conflict of interest}

The authors declare that there are no conflicts of interest. 


\section{Acknowledgements}

The authors thank the numerous fieldworkers who helped with collecting penguin

feathers, F. Capoulun for the preparation of feather samples, G. Guillou and P. Richard for running stable isotope analysis, and P. Blévin for running part of the $\mathrm{Hg}$ analysis. The present work was supported financially and logistically by the Poitou-Charentes Region, the University of La Rochelle, the Agence Nationale de la Recherche (program POLARTOP, O. Chastel), the Institut Polaire Français Paul Emile Victor (IPEV, program no. 109, H. Weimerskirch) and the Terres Australes et Antarctiques Françaises (TAAF).

\section{References}

Anderson, O.R.J., Phillips, R.A., McDonald, R.A., Shore, R.F., McGill, R.A.R., Bearhop, S., 2009. Influence of trophic position and foraging range on mercury levels within a seabird community. Mar Ecol Prog Ser 375, 277-288.

Appelquist, H., Asbirk, S., Drabæk, I., 1984. Mercury monitoring: Mercury stability in bird feathers. Mar Pollut Bull 15, 22-24.

Bargagli, R., Monaci, F., Sanchez-Hernandez, J.C., Cateni, D., 1998. Biomagnification of mercury in an Antarctic marine coastal food web. Mar Ecol Prog Ser 169, 65-76.

Bearhop, S., Phillips, R.A., Thompson, D.R., Waldron, S., Furness, R.W., 2000. Variability in mercury concentrations of great skuas Catharacta skua: the influence of colony, diet and trophic status inferred from stable isotope signatures. Mar Ecol Prog Ser 195, 261-268.

Becker, P.H., Furness, R.W., Henning, D., 1993. The value of chick feathers to assess spatial and interspecific variation in the mercury contamination of seabirds. Environ Monit Assess 28, 255-262.

Becker, P.H., González-Solís, J., Behrends, B., Croxall, J., 2002. Feather mercury levels in seabirds at South Georgia: influence of trophic position, sex and age. Mar Ecol Prog Ser 243, 261-269.

Blévin, P., Carravieri, A., Jaeger, A., Chastel, O., Bustamante, P., Cherel, Y., 2013. Wide range of mercury contamination in chicks of Southern Ocean seabirds. PLoS ONE 8, e54508.

Bocher, P., Caurant, F., Miramand, P., Cherel, Y., Bustamante, P., 2003. Influence of the diet on the bioaccumulation of heavy metals in zooplankton-eating petrels at Kerguelen archipelago, Southern Indian Ocean. Polar Biol 26, 759-767.

Bond, A.L., Diamond, A.W., 2009. Mercury concentrations in seabird tissues from Machias Seal Island, New Brunswick, Canada. Sci Total Environ 407, 4340-4347. 
Bond, A.L., Hobson, K.A., Branfireun, B.A., 2015. Rapidly increasing methyl mercury in endangered ivory gull (Pagophila eburnea) feathers over a 130 year record. Proc R Soc B $282,20150032$.

Bost, C.A., Cotté, C., Bailleul, F., Cherel, Y., Charrassin, J.B., Guinet, C., Ainley, D.G, Weimerskirch, H., 2009. The importance of oceanic fronts to marine birds and mammals of the southern oceans. J Mar Syst 78, 363-376

Brasso, R.L., Chiaradia, A., Polito, M.J., Raya Rey, A., Emslie, S.D., 2015. A comprehensive assessment of mercury exposure in penguin populations throughout the Southern Hemisphere: Using trophic calculations to identify sources of population-level variation. Mar Pollut Bull 97, 408-418.

Brasso, R.L., Drummond, B.E., Borrett, S.R., Chiaradia, A., Polito, M.J., Rey, A.R., 2013. Unique pattern of molt leads to low intraindividual variation in feather mercury concentrations in penguins. Environ Toxicol Chem 32, 2331-2334.

Brasso, R.L., Polito, M.J., Emslie, S.D., 2014. Multi-tissue analyses reveal limited inter-annual and seasonal variation in mercury exposure in an Antarctic penguin community. Ecotoxicology 1-11.

Braune, B.M., Gaston, A.J., Hobson, K.A., Gilchrist, H.G., Mallory, M.L., 2014. Changes in Food Web Structure Alter Trends of Mercury Uptake at Two Seabird Colonies in the Canadian Arctic. Environ. Sci. Technol. 48, 13246-13252.

Braune, B.M., Outridge, P.M., Fisk, A.T., Muir, D.C.G., Helm, P.A., Hobbs, K., Hoekstra, P.F., Kuzyk, Z.A., Kwan, M., Letcher, R.J., Lockhart, W.L., Norstrom, R.J., Stern, G.A., Stirling, I., 2005. Persistent organic pollutants and mercury in marine biota of the Canadian Arctic: An overview of spatial and temporal trends. Sci Total Environ, Contaminants in Canadian Arctic Biota and Implications for Human Health 351-352, 4-56.

Burger, J., Gochfeld, M., 2004. Marine birds as sentinels of environmental pollution. EcoHealth $1,263-274$.

Burnham, K.P., Anderson, D.R., 2002. Model selection and multi-model inference: a practical information-theoretic approach, Second Edition. ed. Springer, New York.

Bustamante, P., Lahaye, V., Durnez, C., Churlaud, C., Caurant, F., 2006. Total and organic Hg concentrations in cephalopods from the North Eastern Atlantic waters: Influence of geographical origin and feeding ecology. Sci Total Environ 368, 585-596.

Cabana, G., Rasmussen, J.B., 1994. Modelling food chain structure and contaminant bioaccumulation using stable nitrogen isotopes. Nature 372, 255-257.

Cabana, G., Tremblay, A., Kalff, J., Rasmussen, J.B., 1994. Pelagic food chain structure in Ontario lakes: a determinant of mercury levels in lake trout (Salvelinus namaycush). Can J Fish Aquat Sci 51, 381-389.

Carravieri, A., Bustamante, P., Churlaud, C., Cherel, Y., 2013. Penguins as bioindicators of mercury contamination in the Southern Ocean: birds from the Kerguelen Islands as a case study. Sci Total Environ 454-455, 141-148.

Carravieri, A., Cherel, Y., Blévin, P., Brault-Favrou, M., Chastel, O., Bustamante, P., 2014a. Mercury exposure in a large subantarctic avian community. Environ Pollut 190, 51-57. 
Carravieri, A., Bustamante, P., Tartu, S., Meillère, A., Labadie, P., Budzinski, H., Peluhet, L., Barbraud, C., Weimerskirch, H., Chastel, O., Cherel, Y., 2014b. Wandering Albatrosses Document Latitudinal Variations in the Transfer of Persistent Organic Pollutants and Mercury to Southern Ocean Predators. Environ Sci Technol 48, 14746-14755.

Carravieri, A., Bustamante, P., Churlaud, C., Fromant, A., Cherel, Y., 2014c. Moulting patterns drive within-individual variations of stable isotopes and mercury in seabird body feathers: implications for monitoring of the marine environment. Mar Biol 161, 963-968.

Catry, T., Ramos, J.A., Le Corre, M., Kojadinovic, J., Bustamante, P., 2008. The role of stable isotopes and mercury concentrations to describe seabird foraging ecology in tropical environments. Mar Biol 155, 637-647.

Ceia, F.R., Phillips, R.A., Ramos, J.A., Cherel, Y., Vieira, R.P., Richard, P., Xavier, J.C., 2012. Short-and long-term consistency in the foraging niche of wandering albatrosses. Mar Biol, $159,1581-1591$.

Chen, C., Amirbahman, A., Fisher, N., Harding, G., Lamborg, C., Nacci, D., Taylor, D., 2008. Methylmercury in Marine Ecosystems: Spatial Patterns and Processes of Production, Bioaccumulation, and Biomagnification. EcoHealth 5, 399-408.

Cherel, Y., 2008. Isotopic niches of emperor and Adélie penguins in Adélie Land, Antarctica. Mar Biol 154, 813-821.

Cherel, Y., Charrassin, J.B., Challet, E., 1994. Energy and protein requirements for molt in the king penguin Aptenodytes patagonicus. Am J Physiol Regul Integr Comp Physiol 35) 266, R1182-R1188.

Cherel, Y., Ducatez, S., Fontaine, C., Richard, P., Guinet, C., 2008. Stable isotopes reveal the trophic position and mesopelagic fish diet of female southern elephant seals breeding on the Kerguelen Islands. Mar Ecol Prog Ser 370, 239-247.

Cherel, Y., Hobson, K.A., 2007. Geographical variation in carbon stable isotope signatures of marine predators: a tool to investigate their foraging areas in the Southern Ocean. Mar Ecol Prog Ser 329, 281-287.

Cherel, Y., Hobson, K.A., Bailleul, F., Groscolas, R., 2005. Nutrition, physiology, and stable isotopes: New information from fasting and molting penguins. Ecology 86, 2881-2888.

Cherel, Y., Hobson, K.A., Guinet, C., Vanpe, C., 2007. Stable isotopes document seasonal changes in trophic niches and winter foraging individual specialization in diving predators from the Southern Ocean. J Anim Ecol 76, 826-836.

Corsolini, S., 2009. Industrial contaminants in Antarctic biota. J Chromatogr A 1216, 598-612.

Cossa, D., 2013. Marine biogeochemistry: Methylmercury manufacture. Nature Geosci 6, 810811.

Cossa, D., Heimbürger, L.E., Lannuzel, D., Rintoul, S.R., Butler, E.C.V., Bowie, A.R., Averty, B., Watson, R.J., Remenyi, T., 2011. Mercury in the Southern Ocean. Geochim Cosmochim Acta 75, 4037-4052.

Dietz, R., Outridge, P.M., Hobson, K.A., 2009. Anthropogenic contributions to mercury levels in present-day Arctic animals - a review. Sci Total Environ 407, 6120-6131. 
Dietz, R., Sonne, C., Basu, N., Braune, B., O'Hara, T., Letcher, R.J., Scheuhammer, T., Andersen, M., Andreasen, C., Andriashek, D., Asmund, G., Aubail, A., Baagøe, H., Born, E.W., Chan, H.M., Derocher, A.E., Grandjean, P., Knott, K., Kirkegaard, M., Krey, A., Lunn, N., Messier, F., Obbard, M., Olsen, M.T., Ostertag, S., Peacock, E., Renzoni, A., Rigét, F.F., Skaare, J.U., Stern, G., Stirling, I., Taylor, M., Wiig, Ø., Wilson, S., Aars, J., 2013. What are the toxicological effects of mercury in Arctic biota? Sci Total Environ 443, 775-790.

Driscoll, C.T., Mason, R.P., Chan, H.M., Jacob, D.J., Pirrone, N., 2013. Mercury as a Global Pollutant: Sources, Pathways, and Effects. Environ Sci Technol 47, 4967-4983.

Fitzgerald, W.F., Lamborg, C.H., Hammerschmidt, C.R., 2007. Marine biogeochemical cycling of mercury. Chem Rev 107, 641-662.

Fontaine, M., Carravieri, A., Simon-Bouhet, B., Bustamante, P., Gasco, N., Bailleul, F., Guinet, C., Cherel, Y., 2015. Ecological tracers and at-sea observations document the foraging ecology of southern long-finned pilot whales (Globicephala melas edwardii) in Kerguelen waters. Mar Biol 162, 207-219.

Frias, J.E., Gil, M.N., Esteves, J.L., García Borboroglu, P., Kane, O.J., Smith, J.R., Boersma, P.D., 2012. Mercury levels in feathers of Magellanic penguins. Mar Pollut Bull 64, 12651269.

Furness, R.W., Camphuysen, K.C.J., 1997. Seabirds as monitors of the marine environment. ICES J Mar Sci 54, 726-737.

Furness, R.W., Lewis, S.A., Mills, J.A., 1990. Mercury levels in the plumage of red-billed gulls Larus novaehollandiae scopulinus of known sex and age. Environ Pollut 63, 33-39.

Furness, R.W., Muirhead, S.J., Woodburn, M., 1986. Using bird feathers to measure mercury in the environment: relationships between mercury content and moult. Mar Pollut Bull 17, 2730 .

Goutte, A., Bustamante, P., Barbraud, C., Delord, K., Weimerskirch, H., Chastel, O., 2014. Demographic responses to mercury exposure in two closely-related Antarctic top predators. Ecology 95, 1075-1086.

Goutte, A., Cherel, Y., Churlaud, C., Ponthus, J.-P., Massé, G., Bustamante, P., 2015. Trace elements in Antarctic fish species and the influence of foraging habitats and dietary habits on mercury levels. Sci Total Environ 538, 743-749.

Hermanns, Y.-M., Biester, H., 2013. Anthropogenic mercury signals in lake sediments from southernmost Patagonia, Chile. Sci Total Environ 445-446, 126-135.

Hilton G.M., Thompson D.R., Sagar P.M., Cuthbert R.J., Cherel Y., Bury J.S., 2006. A stable isotopic investigation into the causes of decline in a sub-Antarctic predator, the rockhopper penguin Eudyptes chrysocome. Glob Chang Biol 12, 611-625.

Honda, K., Yamamoto, Y., Hidaka, H., Yatsukawa, R., 1986. Heavy metal accumulations in Adélie penguin, Pygoscelis adeliae, and their variations with the reproductive processes. Memoirs of National Institute of Polar Research Special Issue, 443-453.

Jaeger, A., Cherel, Y., 2011. Isotopic investigation of contemporary and historic changes in penguin trophic niches and carrying capacity of the Southern Indian Ocean. PLoS ONE 6, e16484. 
Keeling, C.D., 1979. The Suess effect: 13Carbon-14Carbon interrelations. Environment International 2, 229-300.

Kojadinovic, J., Potier, M., Le Corre, M., Cosson, R.P., Bustamante, P., 2006. Mercury content in commercial pelagic fish and its risk assessment in the Western Indian Ocean. Sci Total Environ 366, 688-700.

Lamborg, C.H., Hammerschmidt, C.R., Bowman, K.L., Swarr, G.J., Munson, K.M., Ohnemus, D.C., Lam, P.J., Heimburger, L.-E., Rijkenberg, M.J.A., Saito, M.A., 2014. A global ocean inventory of anthropogenic mercury based on water column measurements. Nature 512, 6568.

Lescroël, A., Ridoux, V., Bost, C.A., 2004. Spatial and temporal variation in the diet of the gentoo penguin (Pygoscelis рариа) at Kerguelen Islands. Polar Biol 27, 206-216.

Lock, J.W., Thompson, D.R., Furness, R.W., Bartle, J.A., 1992. Metal concentrations in seabirds of the New Zealand region. Environ Pollut 75, 289-300.

Mason, R.P., Choi, A.L., Fitzgerald, W.F., Hammerschmidt, C.R., Lamborg, C.H., Soerensen, A.L., Sunderland, E.M., 2012. Mercury biogeochemical cycling in the ocean and policy implications. Environ Res 119, 101-117.

Miller, K.M., Karnovsky, N.J., Trivelpiece, W.Z., 2009. Flexible foraging strategies of gentoo penguins Pygoscelis papua over 5 years in the South Shetland Islands, Antarctica. Mar Biol $156,2527-2537$.

Monteiro, L.R., Furness, R.W., 2001. Kinetics, Dose-Response, and Excretion of Methylmercury in Free-Living Adult Cory's Shearwaters. Environ Sci Technol 35, 739-746.

Monteiro, L.R., Furness, R.W., 1997. Accelerated increase in mercury contamination in north Atlantic mesopelagic food chains as indicated by time series of seabird feathers. Environ Toxicol Chem 16, 2489-2493.

Muir, D., Braune, B., DeMarch, B., Norstrom, R., Wagemann, R., Lockhart, L., Hargrave, B., Bright, D., Addison, R., Payne, J., Reimer, K., 1999. Spatial and temporal trends and effects of contaminants in the Canadian Arctic marine ecosystem: a review. Sci Total Environ 230, 83-144.

Newsome, S.D., Martinez del Rio, C., Bearhop, S., Phillips, D.L., 2007. A niche for isotopic ecology. Front Ecol Environ 5, 429-436.

Offredo, C., Ridoux, V., 1986. The diet of emperor penguins Aptenodytes forsteri in Adélie Land, Antarctica. Ibis 128, 409-413.

Pedro, S., Xavier, J.C., Tavares, S., Trathan, P.N., Ratcliffe, N., Paiva, V.H., Medeiros, R., Vieira, R.P., Ceia, F.R., Pereira, E., Pardal, M.A., 2015. Mercury accumulation in gentoo penguins Pygoscelis papua: spatial, temporal and sexual intraspecific variations. Polar Biol 38, 13351343.

Point, D., Sonke, J.E., Day, R.D., Roseneau, D.G., Hobson, K.A., Vander Pol, S.S., Moors, A.J., Pugh, R.S., Donard, O.F.X., Becker, P.R., 2011. Methylmercury photodegradation influenced by sea-ice cover in Arctic marine ecosystems. Nat Geosci 4, 188-194.

Rau, G.H., Takahashi, T., Des Marais, D.J., Repeta, D.J., Martin, J.H., 1992. The relationship between $\delta^{13} \mathrm{C}$ of organic matter and $\left[\mathrm{CO}_{2}(\mathrm{aq})\right]$ in ocean surface water: Data from a JGOFS site in the northeast Atlantic Ocean and a model. Geochim Cosmochim Acta 56, 1413-1419. 
R Core Team, 2012. R: a language and environment for statistical computing. R Foundation for Statistical Computing, Vienna, Austria.

Ridoux, V., 1994. The diets and dietary segregation of seabirds at the subantarctic Crozet Islands. Mar Ornithol 22, 1-192.

Ridoux V, Offredo C (1989) The diets of five summer breeding seabirds in Adélie Land, Antarctica. Polar Biol 9, 137-145.

Scheifler, R., Gauthier-Clerc, M., Bohec, C.L., Crini, N., Cøeurdassier, M., Badot, P.M., Giraudoux, P., Maho, Y.L., 2005. Mercury concentrations in king penguin (Aptenodytes patagonicus) feathers at Crozet Islands (sub-Antarctic): Temporal trend between 1966-1974 and 2000-2001. Environ Toxicol Chem 24, 125-128.

Stewart, F.M., Phillips, R.A., Bartle, J.A., Craig, J., Shooter, D., 1999. Influence of phylogeny, diet, moult schedule and sex on heavy metal concentrations in New Zealand Procellariiformes. Mar Ecol Prog Ser 178, 295-305.

Stewart, F.M., Phillips, R.A., Catry, P., Furness, R.W., 1997. Influence of species, age and diet on mercury concentrations in Shetland seabirds. Mar Ecol Prog Ser 151, 237-244.

Tartu, S., Goutte, A., Bustamante, P., Angelier, F., Moe, B., Clément-Chastel, C., Bech, C., Gabrielsen, G.W., Bustnes, J.O., Chastel, O., 2013. To breed or not to breed: endocrine response to mercury contamination by an Arctic seabird. Biol Lett 9, 20130317.

Thiebot, J.B., Cherel, Y., Trathan, P.N., Bost, C.A., 2012. Coexistence of oceanic predators on wintering areas explained by population-scale foraging segregation in space or time. Ecology 93, 122-130.

Thiebot, J.B., Cherel, Y., Trathan, P.N., Bost, C.A., 2011a. Inter-population segregation in the wintering areas of macaroni penguins. Mar Ecol Prog Ser 421, 279-290.

Thiebot, J.B., Lescroël, A., Pinaud, D., Trathan, P.N., Bost, C.A., 2011b. Larger foraging range but similar habitat selection in non-breeding versus breeding sub-Antarctic penguins. Antarct Sci 23, 117-126.

Thompson, D.R., Bearhop, S., Speakman, J.R., Furness, R.W., 1998. Feathers as a means of monitoring mercury in seabirds: insights from stable isotope analysis. Environ Pollut 101, 193-200.

Thompson, D.R., Furness, R.W., Lewis, S.A., 1993. Temporal and spatial variation in mercury concentrations in some albatrosses and petrels from the sub-Antarctic. Polar Biol 13, 239244.

Thompson, D.R., Furness, R.W., Walsh, P.M., 1992. Historical changes in mercury concentrations in the marine ecosystem of the north and north-east Atlantic ocean as indicated by seabird feathers. J Appl Ecol 79-84.

Tremblay, Y., Cherel, 2003. Geographic variation in the foraging behaviour, diet and chick growth of rockhopper penguins. Mar Ecol Prog Ser 251, 279-297.

UNEP, U., 2013. Global Mercury Assessment: Sources, Emissions, Releases and Environmental Transport. Geneva, Switzerland.

Vanderklift, M.A., Ponsard, S., 2003. Sources of variation in consumer-diet $\delta^{15} \mathrm{~N}$ enrichment: a meta-analysis. Oecologia 136, 169-182. 
Vo, A.-T.E., Bank, M.S., Shine, J.P., Edwards, S.V., 2011. Temporal increase in organic mercury in an endangered pelagic seabird assessed by century-old museum specimens. Proceedings of the National Academy of Sciences 108, 7466-7471.

Walker, C.H., Sibly, R.M., Hopkin, S.P., Peakall, D.B., 2012. Principles of Ecotoxicology, Fourth Edition. CRC Press.

Wienecke, B.C., Lawless, R., Rodary, D., Bost, C.-A., Thomson, R., Pauly, T., Robertson, G., Kerry, K.R., LeMaho, Y., 2000. Adélie penguin foraging behaviour and krill abundance along the Wilkes and Adélie land coasts, Antarctica. Deep-Sea Res Pt II 47, 2573-2587.

Williams, T.D., 1995. The penguins: Spheniscidae. Oxford University Press.

Wilson, L.J., Daunt, F., Wanless, S., 2004. Self-feeding and chick provisioning diet differ in the Common Guillemot Uria aalge. Ardea 92, 197-207.

Wolfe, M.F., Schwarzbach, S., Sulaiman, R.A., 1998. Effects of mercury on wildlife: a comprehensive review. Environ Toxicol Chem 17, 146-160.

Yamamoto, Y., Kanesaki, S., Kuramochi, T., Miyazaki, N., Watanuki, Y., Naito, Y., 1996. Comparison of trace element concentrations in tissues of the chick and adult Adelie Penguins. Proc. NIPR Symposium Polar Biol 9, 253-262.

Zimmer, I., Wilson, R.P., Gilbert, C., Beaulieu, M., Ancel, A., Plötz, J., 2008. Foraging movements of emperor penguins at Pointe Géologie, Antarctica. Polar Biol 31, 229-243.

Zuur, A.F., Ieno, E.N., Elphick, C.S., 2010. A protocol for data exploration to avoid common statistical problems. Methods Ecol Evol 1, 3-14.

Zuur, A.F., Ieno, E.N., Walker, N., 2009. Mixed Effects Models and Extensions in Ecology with R. Springer. 
Table 1. Foraging ecology of penguins during the breeding and non-breeding periods at three sites of the French Antarctic Territories (TAAF).

\begin{tabular}{|c|c|c|c|c|}
\hline \multirow[t]{2}{*}{ Species } & \multicolumn{2}{|l|}{ Foraging habitat } & \multirow{2}{*}{$\begin{array}{l}\text { Chick diet } \\
\text { (main prey group) }\end{array}$} & \multirow[t]{2}{*}{ References } \\
\hline & $\begin{array}{l}\text { Breeding season } \\
\text { (horizontal; vertical) }\end{array}$ & Non-breeding season & & \\
\hline \multicolumn{5}{|l|}{ Adélie land (Antarctica) } \\
\hline Emperor penguin & $\begin{array}{l}\text { Antarctic waters (neritic; pelagic, } \\
\text { benthic) }\end{array}$ & Antarctic waters (likely oceanic) & Fish & $\begin{array}{l}\text { Offredo and Ridoux (1986); } \\
\text { Cherel (2008) ; Zimmer et al. } \\
\text { (2008) }\end{array}$ \\
\hline Adélie penguin & Antarctic waters (neritic; epi-pelagic) & Antarctic waters & Crustaceans (fish) & $\begin{array}{l}\text { Ridoux and Offredo (1989); } \\
\text { Wienecke et al. (2000); Cherel } \\
\text { (2008) }\end{array}$ \\
\hline \multicolumn{5}{|c|}{ Crozet Islands (Subantarctic Zone) } \\
\hline King penguin & $\begin{array}{l}\text { Polar Frontal Zone } \\
\text { (oceanic; pelagic) }\end{array}$ & Southern Ocean (oceanic) & Mesopelagic fish & $\begin{array}{l}\text { Ridoux (1994); Cherel et al. } \\
\text { (2007); Bost et al. (2009) }\end{array}$ \\
\hline Macaroni penguin & $\begin{array}{l}\text { Polar Frontal Zone } \\
\text { (oceanic; epi-pelagic) }\end{array}$ & $\begin{array}{l}\text { Subantarctic oceanic waters and Polar } \\
\text { Front }\end{array}$ & $\begin{array}{l}\text { Pelagic crustaceans } \\
\text { (fish) }\end{array}$ & $\begin{array}{l}\text { Ridoux (1994); Thiebot et al. } \\
(2011 \mathrm{a}, \mathrm{b})\end{array}$ \\
\hline Southern rockhopper penguin & Crozet waters (neritic; epi-pelagic) & $\begin{array}{l}\text { Subantarctic oceanic waters and Polar } \\
\text { Front }\end{array}$ & Pelagic crustaceans & $\begin{array}{l}\text { Ridoux (1994); Tremblay and } \\
\text { Cherel (2003); Cherel et al. } \\
\text { (2007); Thiebot et al. (2012) }\end{array}$ \\
\hline Gentoo penguin & $\begin{array}{l}\text { Crozet waters (neritic; benthic, epi- } \\
\text { pelagic) }\end{array}$ & Resident all year long & $\begin{array}{l}\text { Pelagic crustaceans } \\
\text { and fish }\end{array}$ & Ridoux (1994) \\
\hline \multicolumn{5}{|c|}{ Amsterdam Island (Subtropical Zone) } \\
\hline Northern rockhopper penguin & $\begin{array}{l}\text { Amsterdam waters (neritic, oceanic; epi- } \\
\text { pelagic) }\end{array}$ & Subtropical oceanic waters & $\begin{array}{l}\text { Pelagic crustaceans } \\
\text { (squid) }\end{array}$ & $\begin{array}{l}\text { Tremblay and Cherel (2003); } \\
\text { Thiebot et al. (2012) }\end{array}$ \\
\hline
\end{tabular}


Table 2. Feather $\mathrm{Hg}$ concentrations $\left(\mu \mathrm{g} \mathrm{g}^{-1} \mathrm{dw}\right.$ ) and $\delta^{13} \mathrm{C}$ and $\delta^{15} \mathrm{~N}$ values (\%) of seven penguin species in 2006 and 2007 . Values are means $\pm \mathrm{SD}$ with ranges in parentheses for $\mathrm{Hg}$.

\begin{tabular}{|c|c|c|c|c|c|c|c|}
\hline $\begin{array}{l}\text { Species } \\
\quad \text { Age class }\end{array}$ & Feather & Year & $n$ & $\mathbf{H g}^{\mathrm{a}}$ & $\begin{array}{l}\text { Adult:Chick } \\
\text { Hg ratio }\end{array}$ & $\delta^{13} \mathbf{C}^{\mathrm{a}}$ & $\delta^{15} \mathbf{N}^{a}$ \\
\hline \multicolumn{8}{|c|}{ Adélie land (Antarctica) } \\
\hline \multicolumn{8}{|c|}{ Emperor penguin, Aptenodytes forsteri } \\
\hline Adult & Old & 2007 & 17 & $1.77 \pm 0.37(1.05-2.76) \mathbf{A}$ & 2.9 & $-23.1 \pm 0.3 \mathbf{A}$ & $12.1 \pm 0.3 \mathbf{A}$ \\
\hline Chick & New & 2007 & 12 & $0.61 \pm 0.11(0.44-0.86) \mathbf{a}$ & & $-24.2 \pm 0.3 \mathbf{a}$ & $12.4 \pm 0.4 \mathbf{a}$ \\
\hline \multicolumn{8}{|c|}{ Adélie penguin, Pygoscelis adeliae } \\
\hline Adult & New & 2007 & 10 & $0.66 \pm 0.20(0.41-1.06) \mathbf{B}$ & 3.5 & $-23.4 \pm 0.4 \mathbf{A}$ & $10.7 \pm 0.6 \mathbf{B}$ \\
\hline Adult & Old & 2006 & 12 & $0.43 \pm 0.13(0.24-0.72)$ & & & \\
\hline Chick & New & 2007 & 10 & $0.19 \pm 0.06(0.07-0.27) \mathbf{b}$ & & $-23.5 \pm 0.2 \mathbf{b}$ & $10.7 \pm 0.4 \mathbf{b}$ \\
\hline \multicolumn{8}{|c|}{ Crozet Islands (Subantarctic Zone) } \\
\hline \multicolumn{8}{|c|}{ King penguin, Aptenodytes patagonicus } \\
\hline Adult & New & 2007 & 12 & $2.89 \pm 0.73(2.13-4.47) \mathbf{C}$ & 1.6 & $-20.8 \pm 0.6 \mathbf{B}$ & $11.3 \pm 0.5 \mathbf{B}, \mathbf{C}$ \\
\hline Adult & Old & 2006 & 12 & $2.94 \pm 0.47(2.15-3.63)$ & & & \\
\hline Chick & New & 2007 & 12 & $1.80 \pm 0.24(1.33-2.11) \mathbf{c}$ & & $-21.6 \pm 0.3 \mathbf{c}$ & $10.5 \pm 0.4 \mathbf{b}$ \\
\hline \multicolumn{8}{|c|}{ Macaroni penguin, Eudyptes chrysolophus } \\
\hline Adult & New & 2007 & 12 & $2.48 \pm 0.35(1.82-2.92) \mathbf{C}$ & 5.8 & $-21.1 \pm 0.3 \mathbf{B}$ & $9.7 \pm 0.3 \mathbf{D}$ \\
\hline Adult & Old & 2006 & 12 & $2.09 \pm 0.31(1.65-2.51)$ & & & \\
\hline Chick & New & 2007 & 12 & $0.43 \pm 0.10(0.31-0.64) \mathbf{d}$ & & $-19.6 \pm 0.2 \mathbf{d}$ & $9.1 \pm 0.5 \mathbf{c}$ \\
\hline \multicolumn{8}{|c|}{ Southern rockhopper penguin, Eudyptes chrysocome filholi } \\
\hline Adult & New & 2007 & 12 & $1.79 \pm 0.37(1.20-2.51) \mathbf{A}$ & 5.3 & $-21.1 \pm 0.2 \mathbf{B}$ & $8.9 \pm 0.4 \mathbf{E}$ \\
\hline Adult & Old & 2006 & 12 & $1.62 \pm 0.35(1.26-2.51)$ & & & \\
\hline Chick & New & 2007 & 12 & $0.34 \pm 0.05(0.25-0.43) \mathbf{d}$ & & $-19.9 \pm 0.2 \mathbf{d}$ & $7.7 \pm 0.6 \mathbf{d}$ \\
\hline \multicolumn{8}{|c|}{ Gentoo penguin, Pygoscelis papиа } \\
\hline Adult & New & 2007 & $11^{*}$ & $5.90 \pm 1.91(3.27-8.16) \mathbf{D}$ & 3.1 & $-19.1 \pm 0.2 \mathbf{C}$ & $11.1 \pm 0.8 \mathbf{B}, \mathbf{C}$ \\
\hline Adult & Old & 2006 & 12 & $5.23 \pm 1.12(3.39-7.40)$ & & & \\
\hline Chick & New & 2007 & 12 & $1.88 \pm 0.46(1.29-2.88) \mathbf{c}$ & & $-19.7 \pm 0.6 \mathbf{d}$ & $9.7 \pm 0.7 \mathbf{c}$ \\
\hline \multicolumn{8}{|c|}{ Amsterdam Island (Subtropical Zone) } \\
\hline \multicolumn{8}{|c|}{ Northern rockhopper penguin, Eudyptes moseleyi } \\
\hline Adult & New & 2007 & 12 & $1.82 \pm 0.30(1.42-3.34) \mathbf{A}$ & 5.4 & $-17.9 \pm 0.2 \mathbf{D}$ & $11.3 \pm 0.4 \mathbf{C}$ \\
\hline Adult & Old & 2006 & 12 & $2.10 \pm 0.36(1.56-2.86)$ & & & \\
\hline Chick & New & 2007 & 15 & $0.34 \pm 0.07(0.25-0.46) \mathbf{d}$ & & $-17.4 \pm 0.2 \mathbf{e}$ & $9.6 \pm 0.4 \mathbf{c}$ \\
\hline
\end{tabular}

* One outlier individual excluded for $\mathrm{Hg}: 16.85 \mu \mathrm{g} \mathrm{g}{ }^{-1} \mathrm{dw}$

${ }^{a}$ Groups with the same letter are not statistically different (Tukey's HSD, $p<0.05$ ). Upper and lower-case letters are for adults and chicks, respectively. 
Table 3. AICc model ranking of latitudinal and historical feather $\mathrm{Hg}$ concentrations in penguin species from the French Austral Territories. Models are GLM with a gamma distribution and an inverse link function. Abbreviations: AICc, Akaike's Information Criteria adjusted for small sample sizes values; wi, AICc weights.

Models $^{\mathrm{a}}$

$k^{\mathrm{b}} \quad \mathrm{AIC}_{\mathrm{c}} \quad \Delta \mathrm{AIC}_{\mathrm{c}}^{\mathrm{c}} \quad w_{i}^{\mathrm{d}} \quad$ Exp. var. ${ }^{\mathrm{e}}$

\section{Latitudinal variation}

Adults, GLM, Gamma distribution, Inverse Link Function, $N=86$

$\begin{array}{llllll}\text { Species }+\delta^{15} \mathrm{~N} & 8 & 108 & 0 & 0.66 & 0.89 \\ \text { Species }+\delta^{15} \mathrm{~N}+\delta^{13} \mathrm{C} & 9 & 110 & 1.35 & 0.34 & 0.89 \\ \text { Species }+\delta^{15} \mathrm{~N}+\text { species: } \delta^{15} \mathrm{~N} & 14 & 119 & 10.3 & 0 & 0.90 \\ \text { Species } & 7 & 127 & 18.7 & 0 & 0.86 \\ \text { Species }+\delta^{13} \mathrm{C} & 8 & 129 & 20.7 & 0 & 0.86 \\ \text { Null } & 1 & 288 & 181 & 0 & 0\end{array}$

Chicks, GLM, Gamma distribution, Inverse Link Function, $N=83$

Species $+\delta^{13} \mathrm{C}+$ species: $\delta^{13} \mathrm{C}$

$\begin{array}{lllll}14 & -107 & 0 & 0.90 & 0.95 \\ 8 & -101 & 5.65 & 0.05 & 0.94 \\ 8 & -99 & 7.65 & 0.02 & 0.94 \\ 9 & -99 & 8.17 & 0.02 & 0.94 \\ 7 & -98 & 9.22 & 0.01 & 0.94 \\ 1 & 126 & 232 & 0 & 0\end{array}$

Species $+\delta^{13} \mathrm{C}$

Species $+\delta^{15} \mathrm{~N}$

Species $+\delta^{13} \mathrm{C}+\delta^{15} \mathrm{~N}$

Species

Null

126

\section{Historical variation}

Adults, GLM, Gamma distribution, Inverse Link Function, $N=124$

$\begin{array}{llllll}\delta^{13} \mathrm{C}+\delta^{15} \mathrm{~N}+\text { epoch }+ \text { species }+\delta^{13} \mathrm{C}: \text { epoch }+\delta^{15} \mathrm{~N} \text { :epoch }+ & 14 & 201 & 0 & 1 & 0.83 \\ \text { species:epoch } & 5 & 279 & 78 & 0 & 0.63 \\ \delta^{13} \mathrm{C}+\delta^{15} \mathrm{~N}+\text { epoch }+\delta^{13} \mathrm{C}: \text { epoch } & 6 & 281 & 80 & 0 & 0.63 \\ \delta^{13} \mathrm{C}+\delta^{15} \mathrm{~N}+\text { epoch }+\delta^{13} \mathrm{C}: \text { epoch }+\delta^{15} \mathrm{~N}: \text { epoch } & 9 & 284 & 83 & 0 & 0.64 \\ \delta^{13} \mathrm{C}+\delta^{15} \mathrm{~N}+\text { epoch }+ \text { species }+\delta^{13} \mathrm{C}: \text { epoch } & 10 & 287 & 86 & 0 & 0.64 \\ \delta^{13} \mathrm{C}+\delta^{15} \mathrm{~N}+\text { epoch }+ \text { species }+\delta^{13} \mathrm{C}: \text { epoch }+\delta^{15} \mathrm{~N}: \text { epoch } & 1 & 397 & 196 & 0 & 0 \\ \text { Null } & & & \end{array}$

\footnotetext{
${ }^{a}$ Only the five best ranked and the null models are presented

${ }^{\mathrm{b}}$ Number of parameters

${ }^{\mathrm{c}}$ Scaled $\triangle \mathrm{AIC} \mathrm{C}_{\mathrm{c}} ; \Delta \mathrm{AIC}_{\mathrm{c}}=0.00$ is interpreted as the best fit to the data among the models

${ }^{\mathrm{d}}$ Weight of evidence interpreted as a proportion. Weights across all models sum to 1.00

${ }^{\mathrm{e}}$ Explained variation calculated from deviance and adjusted depending on $k$ and $N$
} 
Table 4. Feather $\mathrm{Hg}$ concentrations $\left(\mu \mathrm{g} \mathrm{g}^{-1} \mathrm{dw}\right.$ ) in adult penguins across the Southern Hemisphere. Values are means \pm SD with ranges in parentheses when available. Studies with $n$ $<4$ have been excluded.

\begin{tabular}{|c|c|c|c|c|c|}
\hline Species & Site & Zone & $n$ & Hg & Reference \\
\hline African penguin & $\begin{array}{l}\text { South Africa } \\
\text { (Robben Island) }\end{array}$ & $\begin{array}{l}\text { Subtro } \\
\text { pical }\end{array}$ & $\begin{array}{l}1 \\
0\end{array}$ & $\begin{array}{l}0.90 \pm \\
0.35\end{array}$ & $\begin{array}{l}\text { Brasso et al. } \\
(2013)\end{array}$ \\
\hline $\begin{array}{l}\text { Spheniscus } \\
\text { demersus }\end{array}$ & South Africa & $\begin{array}{l}\text { Subtro } \\
\text { pical }\end{array}$ & $\begin{array}{l}1 \\
9\end{array}$ & $\begin{array}{l}1.00 \pm \\
0.44\end{array}$ & $\begin{array}{l}\text { Brasso et al. } \\
(2015)\end{array}$ \\
\hline $\begin{array}{l}\text { Magellanic } \\
\text { penguin } \\
\text { Spheniscus } \\
\text { magellanicus }\end{array}$ & $\begin{array}{l}\text { Patagonia } \\
\text { (Argentina) } \\
\text { South America } \\
\text { (Isla Martillo) } \\
\text { South America } \\
\text { (Isla Martillo) } \\
\text { South America } \\
\text { (Staten Island) }\end{array}$ & $\begin{array}{l}\text { Subant } \\
\text { arctic } \\
\text { Subant } \\
\text { arctic } \\
\text { Subant } \\
\text { arctic } \\
\text { Subant } \\
\text { arctic }\end{array}$ & $\begin{array}{l}2 \\
1 \\
1 \\
0 \\
1 \\
6 \\
1 \\
8\end{array}$ & $\begin{array}{l}0.21 \pm \\
0.10 \\
1.67 \pm \\
0.22 \\
1.79 \pm \\
0.34 \\
2.91 \pm \\
0.56\end{array}$ & $\begin{array}{l}\text { Frias et al. } \\
(2012) \\
\text { Brasso et } \\
(2013) \\
\text { Brasso et } \\
(2015) \\
\text { Brasso et } \\
(2015)\end{array}$ \\
\hline $\begin{array}{l}\text { Emperor penguin } \\
\text { Aptenodytes } \\
\text { forsteri }\end{array}$ & $\begin{array}{l}\text { Antarctica (Adélie } \\
\text { land) }\end{array}$ & $\begin{array}{l}\text { Antarct } \\
\text { ic }\end{array}$ & $\begin{array}{l}1 \\
7\end{array}$ & $\begin{array}{l}1.77 \pm \\
0.37\end{array}$ & This study \\
\hline King penguin & South Georgia & $\begin{array}{l}\text { Subant } \\
\text { arctic }\end{array}$ & $\begin{array}{l}1 \\
0\end{array}$ & $\begin{array}{l}2.92 \pm \\
0.76\end{array}$ & $\begin{array}{l}\text { Brasso et al. } \\
(2013)\end{array}$ \\
\hline $\begin{array}{l}\text { Aptenodytes } \\
\text { patagonicus }\end{array}$ & South Georgia & $\begin{array}{l}\text { Subant } \\
\text { arctic }\end{array}$ & $\begin{array}{l}2 \\
0\end{array}$ & $\begin{array}{l}3.01 \pm \\
0.79\end{array}$ & $\begin{array}{l}\text { Brasso et al. } \\
(2015)\end{array}$ \\
\hline & $\begin{array}{l}\text { Kerguelen } \\
\text { Archipelago } \\
\text { Crozet Islands }\end{array}$ & $\begin{array}{l}\text { Subant } \\
\text { arctic } \\
\text { Subant } \\
\text { arctic }\end{array}$ & $\begin{array}{l}1 \\
2 \\
3 \\
1\end{array}$ & $\begin{array}{l}2.22 \pm \\
0.59 \\
1.98 \pm \\
0.73\end{array}$ & $\begin{array}{l}\text { Carravieri et } \\
\text { al. (2013) } \\
\text { Scheifler et al. } \\
(2005)\end{array}$ \\
\hline & Crozet Islands & $\begin{array}{l}\text { Subant } \\
\text { arctic }\end{array}$ & $\begin{array}{l}1 \\
2\end{array}$ & $\begin{array}{l}2.89 \pm \\
0.73\end{array}$ & This study \\
\hline Adélie penguin & $\begin{array}{l}\text { Antarctica (Syowa } \\
\text { Station) }\end{array}$ & $\begin{array}{l}\text { Antarct } \\
\text { ic }\end{array}$ & $\begin{array}{l}1 \\
0\end{array}$ & $\begin{array}{l}0.17 \pm \\
0.05\end{array}$ & $\begin{array}{l}\text { Honda et al. } \\
\text { (1986) }\end{array}$ \\
\hline Pygoscelis adeliae & $\begin{array}{l}\text { Antarctica (Cape } \\
\text { Hinode) } \\
\text { Antarctic } \\
\text { Peninsula } \\
\text { King George } \\
\text { Island } \\
\text { King George } \\
\text { Island } \\
\text { Antarctica (Adélie } \\
\text { land) }\end{array}$ & $\begin{array}{l}\text { Antarct } \\
\text { ic } \\
\text { Antarct } \\
\text { ic } \\
\text { Antarct } \\
\text { ic } \\
\text { Antarct } \\
\text { ic } \\
\text { Antarct } \\
\text { ic }\end{array}$ & $\begin{array}{l}1 \\
0 \\
2 \\
1 \\
1 \\
0 \\
9 \\
8 \\
1 \\
0\end{array}$ & $\begin{array}{l}0.09 \pm \\
0.05 \\
0.35 \pm \\
0.09 \\
0.32 \pm \\
0.08 \\
0.34 \pm \\
0.13 \\
0.66 \pm \\
0.20\end{array}$ & $\begin{array}{l}\text { Yamamoto et } \\
\text { al. (1996) } \\
\text { Brasso et al. } \\
(2015) \\
\text { Brasso et al. } \\
(2013) \\
\text { Brasso et al. } \\
(2014) \\
\text { This study }\end{array}$ \\
\hline Chinstrap penguin & $\begin{array}{l}\text { Antarctic } \\
\text { Peninsula }\end{array}$ & $\begin{array}{l}\text { Antarct } \\
\text { ic }\end{array}$ & $\begin{array}{l}1 \\
6\end{array}$ & $\begin{array}{l}0.62 \pm \\
0.30\end{array}$ & $\begin{array}{l}\text { Brasso et al. } \\
(2015)\end{array}$ \\
\hline $\begin{array}{l}\text { Pygoscelis } \\
\text { antarctica }\end{array}$ & $\begin{array}{l}\text { King George } \\
\text { Island } \\
\text { King George } \\
\text { Island }\end{array}$ & $\begin{array}{l}\text { Antarct } \\
\text { ic } \\
\text { Antarct } \\
\text { ic }\end{array}$ & $\begin{array}{l}1 \\
0 \\
7 \\
0\end{array}$ & $\begin{array}{l}0.69 \pm \\
0.18 \\
0.63 \pm \\
0.24\end{array}$ & $\begin{array}{l}\text { Brasso et al. } \\
(2013) \\
\text { Brasso et al. } \\
(2014)\end{array}$ \\
\hline
\end{tabular}




\begin{tabular}{|c|c|c|c|c|c|}
\hline Gentoo penguin & $\begin{array}{l}\text { Antarctic } \\
\text { Peninsula }\end{array}$ & $\begin{array}{l}\text { Antarct } \\
\text { ic }\end{array}$ & $\begin{array}{l}2 \\
1\end{array}$ & $\begin{array}{l}0.31 \pm \\
0.10\end{array}$ & $\begin{array}{l}\text { Brasso et al. } \\
(2015)\end{array}$ \\
\hline \multirow[t]{14}{*}{ Pygoscelis рариа } & $\begin{array}{l}\text { King George } \\
\text { Island }\end{array}$ & $\begin{array}{l}\text { Antarct } \\
\text { ic }\end{array}$ & $\begin{array}{l}1 \\
0\end{array}$ & $\begin{array}{l}0.28 \pm \\
0.05\end{array}$ & $\begin{array}{l}\text { Brasso et al. } \\
(2013)\end{array}$ \\
\hline & King George & Antarct & 8 & $0.42 \pm$ & Brasso et al. \\
\hline & Island & & 9 & 0.41 & (2014) \\
\hline & South Georgia & Subant & 1 & $0.95 \pm$ & Becker et al. \\
\hline & (Bird Island) & arctic & 4 & 0.85 & (2002) \\
\hline & South Georgia & $\begin{array}{l}\text { Subant } \\
\text { arctic }\end{array}$ & $\begin{array}{l}2 \\
0\end{array}$ & $\begin{array}{l}0.85 \pm \\
0.88\end{array}$ & $\begin{array}{l}\text { Brasso et al. } \\
(2015)\end{array}$ \\
\hline & South Georgia & Subant & 2 & $1.1 \pm$ & Pedro et al. \\
\hline & (Bird istand) & arctic & 9 & 0.02 & $(2015)$. \\
\hline & Kerguelen Islands & Subant & 1 & $5.85 \pm$ & Carravieri \\
\hline & & arctic & & 3.00 & al. $(2015)$ \\
\hline & Kerguelen Islands & Subant & 1 & $1.44 \pm$ & Carravierı \\
\hline & (Penn) & arctic & 2 & 0.44 & al. (2013) \\
\hline & Crozet Islands & Subant & 1 & $5.90 \pm$ & This study \\
\hline & & $\operatorname{arctic}$ & 1 & & \\
\hline Macaroni penguin & $\begin{array}{l}\text { Bird Island (South } \\
\text { Georgia) }\end{array}$ & $\begin{array}{l}\text { Subant } \\
\text { arctic }\end{array}$ & $\begin{array}{l}2 \\
0\end{array}$ & $\begin{array}{l}3.41 \pm \\
0.73\end{array}$ & $\begin{array}{l}\text { Becker et al. } \\
(2002)\end{array}$ \\
\hline \multirow{4}{*}{$\begin{array}{l}\text { Eudyptes } \\
\text { chrysolophus }\end{array}$} & Kerguelen & Subant & 1 & $2.24 \pm$ & Carravieri \\
\hline & Archipelago & $\operatorname{arctic}$ & 2 & 0.29 & al. (2013) \\
\hline & Crozet Islands & Subant & 1 & $2.48 \pm$ & This study \\
\hline & & $\operatorname{arctic}$ & 2 & 0.35 & \\
\hline \multirow{3}{*}{$\begin{array}{l}\text { Northern } \\
\text { rockhopper } \\
\text { penguin } \\
\text { Eudyptes moseleyi }\end{array}$} & Amsterdam Island & Subtro & 1 & $1.82 \pm$ & This study \\
\hline & & pical & 2 & 0.30 & \\
\hline & & & & & \\
\hline \multirow{10}{*}{$\begin{array}{l}\text { Southern } \\
\text { rockhopper } \\
\text { penguin } \\
\text { Eudyptes } \\
\text { chrysocome }\end{array}$} & $\begin{array}{l}\text { South America } \\
\text { (Staten Island) }\end{array}$ & $\begin{array}{l}\text { Subant } \\
\text { arctic }\end{array}$ & $\begin{array}{l}1 \\
0\end{array}$ & $\begin{array}{l}5.44 \pm \\
0.67\end{array}$ & Brasso et al. \\
\hline & & & & & \\
\hline & South America & Subant & 6 & $5.10 \pm$ & Brasso et al. \\
\hline & (Staten Island) & arctic & 1 & 1.46 & $(2015)$ \\
\hline & Kerguelen Islands & Subant & 1 & $1.96 \pm$ & Carravieri \\
\hline & (Mayès) & $\operatorname{arctic}$ & 2 & 0.41 & al. (2013) \\
\hline & Kerguelen Islands & Subant & 1 & $2.54 \pm$ & Unpublished \\
\hline & (Larose) & arctic & 0 & 0.33 & data \\
\hline & Crozet Islands & Subant & 1 & $1.79 \pm$ & This study \\
\hline & & $\operatorname{arctic}$ & 2 & 0.37 & \\
\hline \multirow[t]{2}{*}{ Little blue penguin } & New Zealand & Subtro & 5 & $3.4 \pm$ & Lock et al. \\
\hline & Region & pical & & 3.7 & (1992) \\
\hline \multirow[t]{4}{*}{ Eudyptula minor } & Australia (Phillip & Subtro & 1 & $2.92 \pm$ & Brasso et al. \\
\hline & Island) & pical & 0 & 2.88 & (2013) \\
\hline & Australia (Phillip & Subtro & 1 & $2.00 \pm$ & Brasso et al. \\
\hline & Island) & pical & 9 & 0.77 & (2015) \\
\hline
\end{tabular}


Fig.1. Boxplots of feather $\mathrm{Hg}$ concentration in adults of six penguin species from the French Austral Territories in 2007.
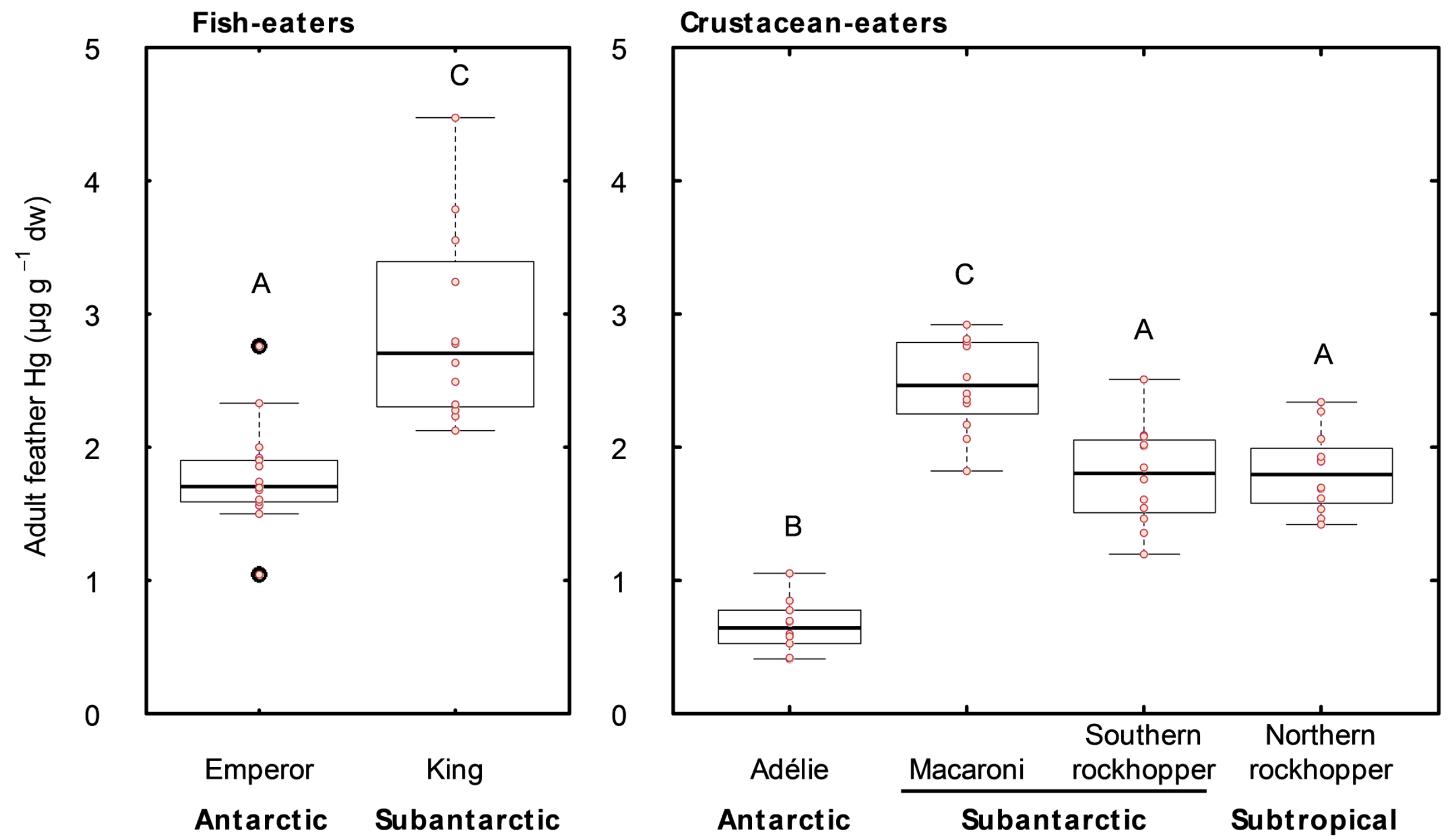
Fig. 2. Positive correlation between feather Hg concentrations $\left(\mu \mathrm{g} \mathrm{g}^{-1} \mathrm{dw}\right)$ of individual adult penguins during two consecutive years (2006 and 2007) from different sites of the French Austral Territories.

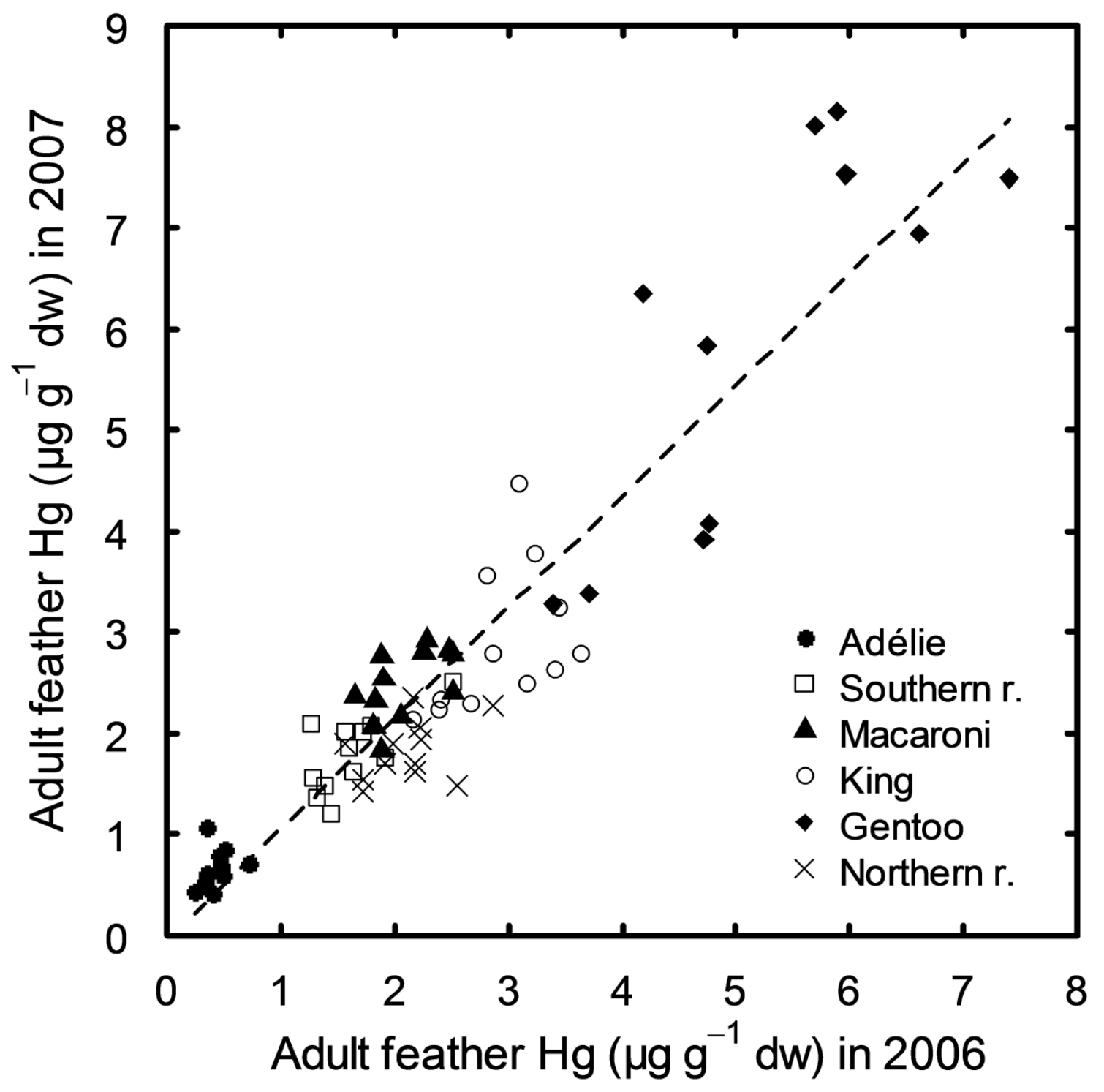


Fig. 3. Boxplots of feather $\mathrm{Hg}$ concentration $\left(\mu \mathrm{g} \mathrm{g}^{-1} \mathrm{dw}\right)$ and $\delta^{15} \mathrm{~N}$ values (\%o) in Antarctic penguin species from the French Austral Territories in the 1950s and in 2007.

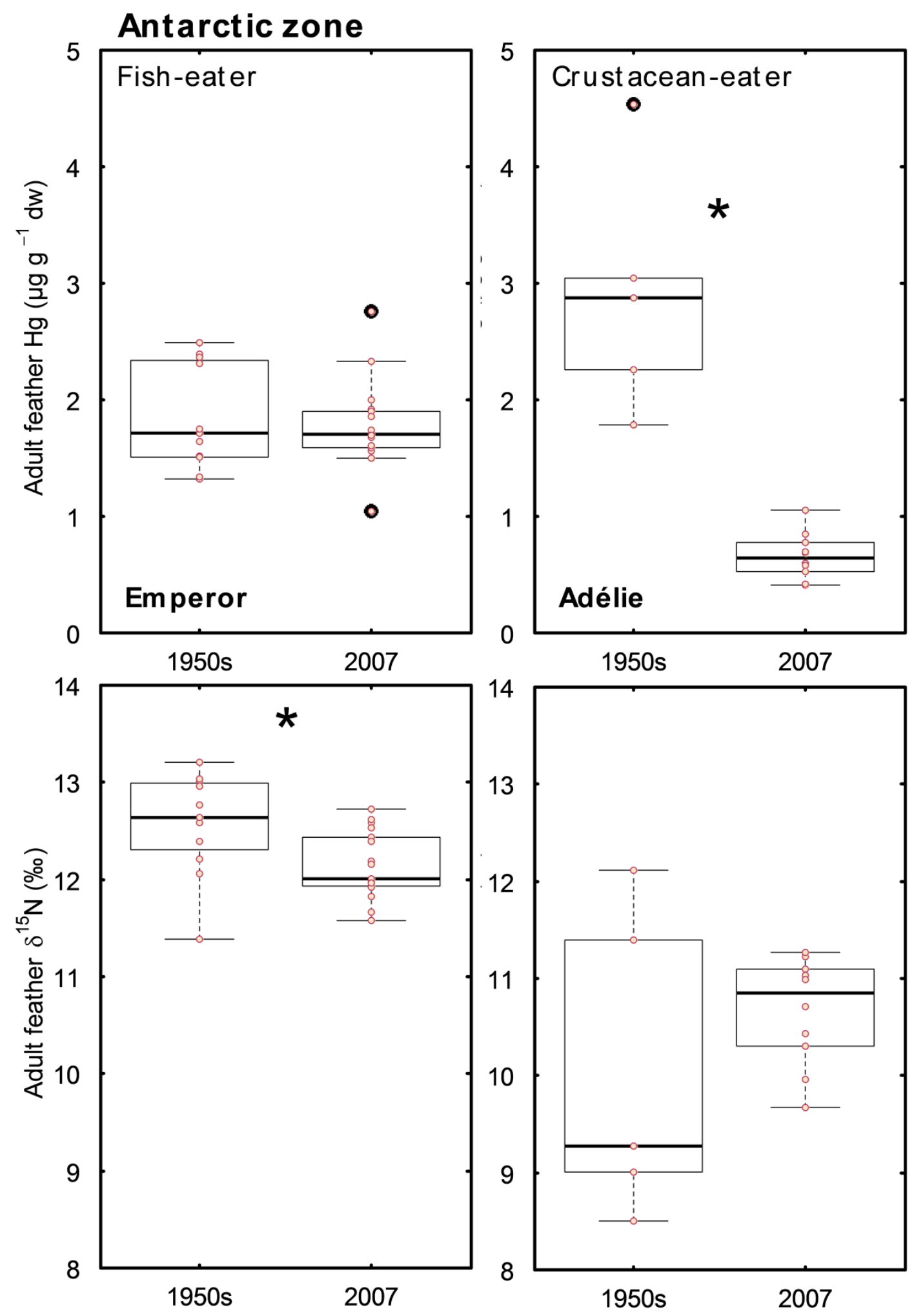


Fig. 4. Boxplots of feather $\mathrm{Hg}$ concentration $\left(\mu \mathrm{g} \mathrm{g}^{-1} \mathrm{dw}\right)$ and $\delta^{15} \mathrm{~N}$ values (\%) in subantarctic penguin species from the French Austral Territories in the 1970s and in 2007.
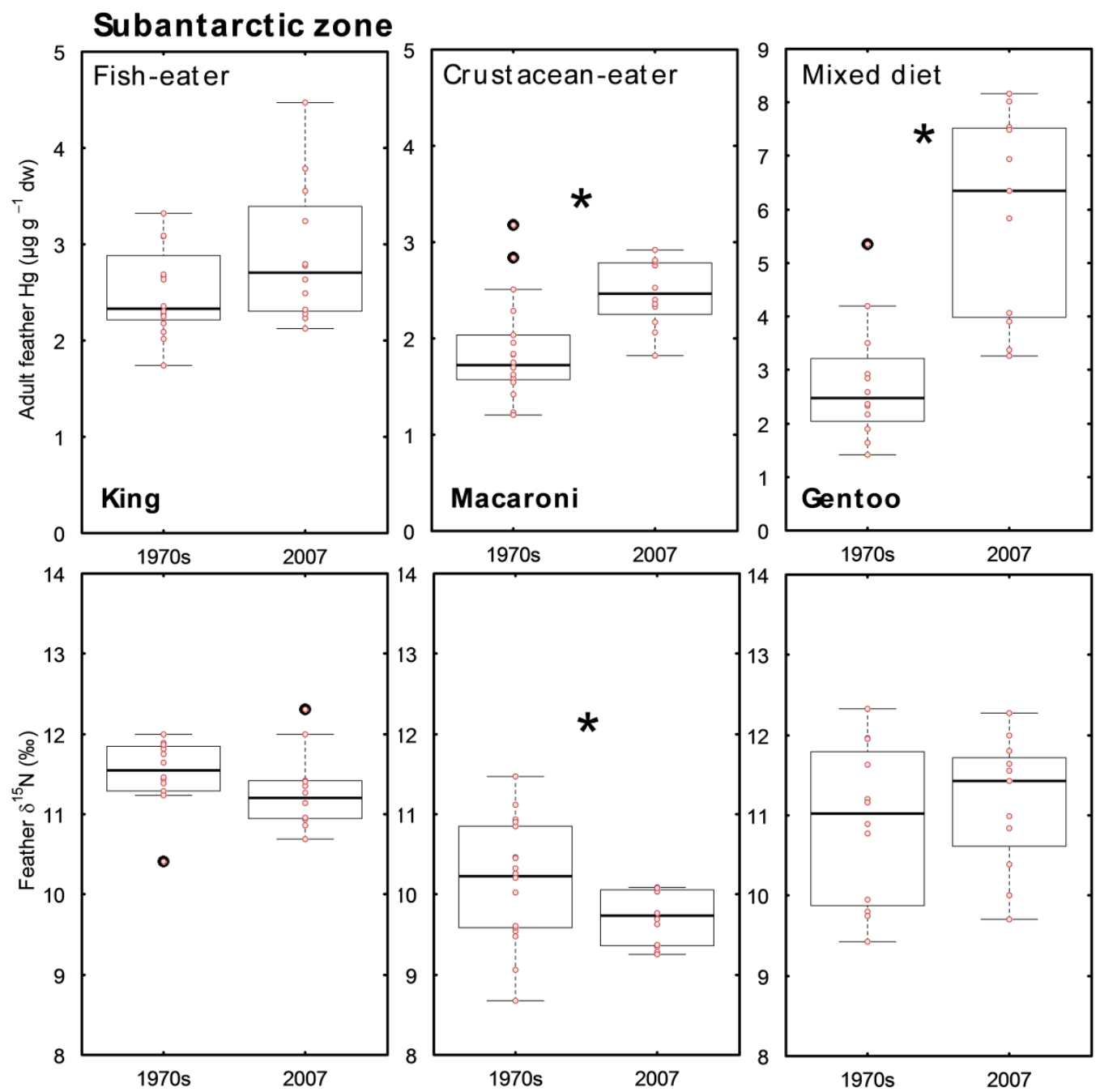
Supplementary Information

Table S1. Feather Hg concentrations ( $\mu \mathrm{g} \mathrm{g} \mathrm{g}^{-1} \mathrm{dw}$ ) and $\delta^{13} \mathrm{C}$ and $\delta^{15} \mathrm{~N}$ values (\%o) of actual (2007) and historical samples (1950s-1970s) in penguin species from Terre Adélie (Antarctica) and the Crozet Islands.

\begin{tabular}{|c|c|c|c|c|c|c|c|c|}
\hline Species & Year & $n$ & \multicolumn{2}{|c|}{$\mathbf{H g}$} & \multicolumn{2}{|r|}{$\delta^{13} C^{1}$} & \multicolumn{2}{|r|}{$\delta^{15} \mathbf{N}$} \\
\hline \multicolumn{3}{|c|}{ Adélie land (Antarctica) } & Mean \pm SD $(\min -\max )$ & $\mathrm{W} ; p$ value ${ }^{2}$ & Mean \pm SD & $\mathrm{t} ; p$ value ${ }^{3}$ & Mean \pm SD & $\mathrm{t} ; p$ value ${ }^{3}$ \\
\hline \multirow[t]{2}{*}{ Emperor } & $1950 \mathrm{~s}$ & 11 & $1.85 \pm 0.45(1.32-2.49)$ & $\mathrm{W}=97 ; \mathrm{p}=0.888$ & $-23.1 \pm 0.4$ & $\mathrm{t}=-1.3 ; \mathrm{p}=0.226$ & $12.7 \pm 0.5$ & $\mathrm{t}=2.3 ; \mathrm{p}=0.034 *$ \\
\hline & 2007 & 17 & $1.77 \pm 0.37(1.05-2.76)$ & & $-23.1 \pm 0.3$ & & $12.2 \pm 0.3$ & \\
\hline \multirow[t]{2}{*}{ Adélie } & $1950 \mathrm{~s}$ & 5 & $2.90 \pm 1.04(1.79-4.53)$ & $\mathrm{W}=50 ; \mathrm{p}=0.001 *$ & $-24.3 \pm 0.4$ & $\begin{array}{l}\mathrm{t}=-5.5 ; \mathrm{p}=0.001 \\
*\end{array}$ & $10.2 \pm 1.6$ & $\mathrm{t}=-0.8 ; \mathrm{p}=0.449$ \\
\hline & 2007 & 10 & $0.66 \pm 0.20(0.41-1.06)$ & & $-23.4 \pm 0.4$ & & $10.7 \pm 0.6$ & \\
\hline \multicolumn{9}{|c|}{ Crozet Islands (Subantarctic Zone) } \\
\hline \multirow[t]{2}{*}{ King } & 1970s & 16 & $2.50 \pm 0.45(1.74-3.32)$ & $\mathrm{W}=65 ; \mathrm{p}=0.157$ & $-20.5 \pm 0.6$ & $\mathrm{t}=-2.1 ; \mathrm{p}=0.051$ & $11.5 \pm 0.4$ & $\mathrm{t}=1.5 ; \mathrm{p}=0.152$ \\
\hline & 2007 & 12 & $2.89 \pm 0.73(2.13-4.47)$ & & $-20.8 \pm 0.6$ & & $11.3 \pm 0.5$ & \\
\hline \multirow[t]{2}{*}{ Macaroni } & 1970s & 18 & $1.88 \pm 0.53(1.21-3.18)$ & $\mathrm{W}=36 ; \mathrm{p}=0.002 *$ & $-20.8 \pm 0.6$ & $\mathrm{t}=3.2 ; \mathrm{p}=0.003 *$ & $10.2 \pm 0.7$ & $\mathrm{t}=2.3 ; \mathrm{p}=0.033 *$ \\
\hline & 2007 & 12 & $2.48 \pm 0.35(1.82-2.92)$ & & $-21.1 \pm 0.3$ & & $9.7 \pm 0.3$ & \\
\hline \multirow[t]{2}{*}{ Gentoo } & $1970 \mathrm{~s}$ & 12 & $2.77 \pm 1.12(1.42-5.35)$ & $\mathrm{W}=10 ; \mathrm{p}<0.001 *$ & $-19.2 \pm 1.2$ & $\begin{array}{l}\mathrm{t}=-2.5 ; \mathrm{p}=0.028 \\
*\end{array}$ & $10.9 \pm 1.0$ & $\mathrm{t}=-0.6 ; \mathrm{p}=0.523$ \\
\hline & 2007 & 12 & $5.90 \pm 1.91(3.27-8.16)$ & & $-19.1 \pm 0.2$ & & $11.2 \pm 0.8$ & \\
\hline
\end{tabular}

${ }^{1}$ Carbon isotopic values were corrected for Suess and increased effects of seawater $\mathrm{CO}_{2}$ concentrations

${ }^{2}$ Wilcoxon comparisons

${ }^{3}$ Welsh two sample $t$ test 